Joaquín Silva Soler

Profesor Facultad de Teología

Pontificia Universidad Católica de Chile

\title{
Hermenéutica y verdad teológica
}

\section{INTRODUCCIÓN}

La pregunta por la verdad pudiera comenzar con las palabras que Pilatos dirigió a Jesús: ¿Y qué es la verdad? Pero comenzar de este modo, en realidad, no es comenzar con una pregunta, sino con una respuesta; quizás, con la respuesta que muchos de nuestros contemporáneos dan a la inevitable pregunta por la verdad. La pregunta tipo Pilatos es la respuesta de quien no ha encontrado respuestas a sus preguntas y, quizás, ya está cansado de buscar; es la respuesta de quien vio desvanecer sus certezas y, quizás hoy, percibe que nada ni nadie se las podrá devolver; es la respuesta de quien no está dispuesto a asumir los compromisos teóricos y prácticos que supone reconocer la verdad y, quizás por temor, prefiere permanecer como espectador, prefiere seguir preguntando, para así no encontrar nunca una respuesta a sus preguntas; es la respuesta de quien ha escuchado tantas respuestas a la pregunta por la verdad que, ya quizás confundido, no atina con ninguna de ellas; es la respuesta de quien ha experimentado, o, quizás sabido, que muchas veces los detentores de "la verdad" han recurrido a los más sucios ardiles del "padre de la mentira" (Jn 8, 44) para imponer a otros su propia voluntad de poder, tener y saber; es la respuesta de quien ha tomado conciencia de la fragilidad de todo conocimiento y experiencia humana y, quizás ya decepcionado, desconfía de las posibilidades de la razón para alcanzar la verdad, "con certeza y sin error". Todas estas son, tanto ayer como hoy, posibilidades reales de tomar posición respecto a la pregunta por la verdad. Sin embargo, la pregunta tipo Pilatos supone otra pregunta por la verdad, pero situada ahora en una existencia interesada en encontrar algún sentido a la vida que sea realmente creíble, confiable, seguro. En efecto, en un sentido originario, "la pregunta por la verdad es la pregunta por el conjunto de aquello que confiadamente podemos saber respecto de nosotros mismos y de nuestro mundo, de aquello a lo cual nos podemos confiar. Verdadero es aquello que vale, que es confiable, que cuenta. Por ello mismo, puede ser tan correcto hablar de un verdadero amigo, como de una verdadera afirmación o de un hecho verdadero" (1).

Sin embargo, este sentido originario e inmediato en el que se comprende la verdad se hace problemático cuando nos preguntamos por las condiciones y posibili-

(1) H.-M. Baumgartner, "Wahrheit/Gewissheit", en: P.Eicher (ed.), Neues Handbuch Theologischer Grundbegriffe, vol. 4, Kösel Verlag, München 1985, 263. 
dades para afirmar que algo pueda ser verdadero: el amigo, la proposición, el hecho, o lo que sea. Aquí la pregunta se plantea en un nivel propiamente filosófico, por cuanto ella se dirige al ser mismo de la verdad (2). Cuando la pregunta se ha orientado de este modo, ello ha tenido diversas consecuencias (3). En primer lugar, la pregunta por la verdad se vuelve teórica, distanciándose la confianza de la validez: solo nos podemos confiar en aquello que pueda acreditar su validez ante la razón, pero el movimiento inverso no es posible. Así, la teoría prevalece sobre la praxis y el conocimiento sobre la acción. Una segunda consecuencia, asociada a la anterior, consiste en la ampliación de nuestro horizonte de preguntas respecto de la verdad, con la consecuente diferenciación de cuestiones específicas a resolver: qué pensamos respecto de la verdad; cómo distinguimos verdad de falsedad; cuáles son sus condiciones y posibilidades; cuáles son sus funciones; cuál es su relevancia, etc. Estas y otras cuestiones se despliegan desde la pregunta fundamental por el significado de la verdad y desde la comprensión -también fundamental- que la verdad acontece cuando nuestro conocimiento coincide con aquello que es. Sin embargo, desde aquí mismo surge la tercera consecuencia de una consideración filosófica de la verdad y que consiste ahora en la pregunta por las condiciones y posibilidades de aquella coincidencia entre ser y conocer. "El conocimiento de la realidad es solamente verdadero -afirma Baumgartner- cuando coinciden ser y conocer. ¿Pero cómo podemos asegurar dicha coincidencia? ¿Bajo qué condiciones pueden coincidir el ser y el conocer, en qué casos concretos se puede reconocer esa coincidencia? Este es el complejo de preguntas que se han levantado en la historia de la reflexión filosófica sobre la verdad y que hasta hoy la determinan" (4).

En su Encíclica Fides et ratio, el Papa Juan Pablo II ha ofrecido un diagnóstico respecto de la cuestión de la verdad que nos ayuda a reconocer aún mejor la profundidad y extensión en que hoy se sitúa la cuestión de la verdad. En este diagnóstico se puede apreciar la presencia de las cuestiones filosófico-fundamentales recién enunciadas, pero, a la vez, ellas mismas se comprenden en un contexto mayor, cuál es el desarrollo de otras formas del pensar -el de la ciencia y la técnica-, como también el desarrollo de nuevas formas de configuración de la vida personal y social. Un primer elemento de este diagnóstico lo constituyen diversas expresiones de una antropología cerrada a la trascendencia. En efecto, el Papa reconoce que los avances científicos y tecnológicos han representado un avance importante en el desarrollo de la cultura, lo mismo que los nuevos conocimientos que se han adquiri-

(2) Es en este mismo contexto existencial donde el Papa Juan Pablo II reconoce el origen del pensar filosófico: "El hombre tiene muchos medios para progresar en el conocimiento de la verdad, de modo que puede hacer cada vez más humana la propia existencia. Entre estos destaca la filosofía, que contribuye directamente a formular la pregunta sobre el sentido de la vida y a trazar la respuesta: esta, en efecto, se configura como una de las tareas más nobles de la humanidad. El término filosofía según la etimología griega significa "amor a la sabiduría". De hecho, la filosofía nació y se desarrolló desde el momento en que el hombre empezó a interrogarse sobre el porqué de las cosas y su finalidad. De modos y formas diversas, muestra que el deseo de verdad pertenece a la naturaleza misma del hombre. El interrogarse sobre el porqué de las cosas es inherente a su razón, aunque las respuestas que se han ido dando se enmarcan en un horizonte que pone en evidencia la complementariedad de las diferentes culturas en las que vive el hombre" (Fides et ratio, n.3).

(3) Sigo aquí el artículo recién citado de Baumgartner, pp. 263 y 264.

(4) H.-M. Baumgartner, "Wahrheit/Gewissheit", art. cit., 264. 
do en el campo de las ciencias sociales, de la psicología, de la historia y del lenguaje. Todo ello está fuera de duda. Sin embargo, advierte el Papa, "los resultados positivos alcanzados no deben llevar a descuidar el hecho de que la razón misma, movida a indagar de forma unilateral sobre el hombre como sujeto, parece haber olvidado que este está también llamado a orientarse hacia una verdad que lo trasciende" (5). No hay aquí demonización alguna de la ciencia y de la técnica, por el contrario, se reconocen sus aportes al desarrollo y comprensión humanas. Sin embargo, sea por la absolutización del método o por la reducción del objeto, desgraciadamente se debe constatar que el "paradigma científico-positivo" efectivamente ha llevado a una comprensión de la verdad cerrada a su propia trascendencia (6).

Un segundo elemento general de este diagnóstico, asociado al anterior, lo constituye una de las cuestiones que quizás más ha rondado en las preocupaciones de este seminario, cuál es la cuestión del relativismo, que, según la Fides et ratio, ha llevado a algunas corrientes filosóficas a perderse en las arenas movedizas de un escepticismo general. Hoy han adquirido fuerza aquellas doctrinas que tienden a infravalorar incluso las verdades que el hombre estaba seguro de haber alcanzado. La legítima pluralidad de posiciones ha dado paso a un pluralismo indiferenciado, basado en el convencimiento de que todas las posiciones son igualmente válidas. Este es uno de los síntomas más difundidos de la desconfianza en la verdad, que es posible encontrar en el contexto actual. Esta desconfianza en la verdad es, en último término, la desconfianza en la razón que manifiesta gran parte de la filosofía contemporánea y que, abandonando las preguntas últimas del hombre, se concentra en los problemas particulares y regionales, a veces incluso puramente formales (7). Hay que decir que esta desconfianza hacia las posibilidades de la razón, como el mismo Papa lo expresa, también se hacen manifiestas en el fideísmo y en el tradicionalismo (8).

Este relativismo hoy ha tomado también las formas de un individualismo egocéntrico, que difícilmente se puede adscribir a una sola corriente de pensamiento y que, en el plano religioso, ha adquirido formas lingüísticas tales como "creo a mi manera" o "yo determino lo que Dios es". Podemos decir que aquello que creemos y los modos históricos en que lo hacemos no son cuestiones que cada cual pueda determinar arbitrariamente: "ya en la formulación de nuestra fe dependemos de otros, de tradiciones, de historias, de formas de vida que nosotros mismos no hemos creado ni descubierto. Si el 'yo determino lo que Dios es' lo tomáramos literalmente, entonces no tendríamos nada más que decirnos, ya no podríamos comprendernos unos a otros" (9). Tiene razón Dalferth cuando recuerda que una tal postura ha quedado desacreditada por la crítica de Wittgenstein a los argumentos linguísticos privados, por los estudios antropológicos de Geertz; o por teólogos como Lindbeck.

(5) Juan Pablo II, Fides et ratio, n.5.

(6) En el número 88 de la Encíclica, se afirma que cientificismo es una "corriente filosófica que no admite como válidas otras formas de conocimiento que no sean las propias de las ciencias positivas, relegando al ámbito de la mera imaginación tanto el conocimiento religioso y teológico, como el saber ético y estético. En el pasado, esta misma idea se expresaba en el positivismo y en el neopositivismo, que consideraban sin sentido las afirmaciones de carácter metafísico".

(7) Cf. Juan Pablo II, Fides et ratio, n. 61

(8) Cf. Juan Pablo II, Fides et ratio, n. 53.

(9) I.-U., Dalferth, “"Was Gott ist”, bestimme ich!” ...”, art. cit., 420. 
Sin embargo, "los porfiados hechos" nos indican que, justamente, hoy es posible reconocerse creyente sin una adhesión a una "comunidad lingüística" particular, sin adoptar la totalidad de las formas cultuales, doctrinales y morales que una determinada religión profesa. Podemos calificar esta nueva forma religiosa como "individualismo egocéntrico" (10), y con autores como los recién mencionados desenmascarar sus insuficiencias tanto teóricas como prácticas; sin embargo, el hecho persiste; más aún, pareciera que se acrecienta y representa, efectivamente, un nuevo modo de vivir la relación con Dios: a mi manera, de acuerdo a una irreductible subjetividad personal, donde los otros pueden seguir siendo un referente significativo de la vida, pero siempre y cuando ello lo pueda determinar yo mismo (11).

Donde el individualismo egocéntrico - que ha asumido formas de comportamiento social- muestra su más radical insuficiencia es, precisamente, de cara a Dios. En primer término, porque en la autoafirmación del sujeto se niega aquello que está en juego en toda religión; esto es, la conciencia de saberse referido a una realidad primera y fundante, que me antecede, que me llama, que me invita, que me sostiene. En el individualismo egocéntrico soy yo quien determino la realidad de Dios y, en esa misma determinación niego a Dios, en cuanto Dios. Pero, en segundo término, porque si la realidad de Dios es la mera determinación del sujeto, entonces "mi Dios", aquel al que yo le he reconocido alguna realidad, ya no puede ser el Dios de los otros, y si no es el Dios de los otros, entonces tampoco puede ser Dios para mí. Como afirma Dalferth, "Dios no puede ser mi Dios, o nuestro Dios, si Él no pudiera ser también el Dios de los demás, de todos los demás" (12).

Un tercer problema que el Papa reconoce en la sociedad contemporánea, que toca el centro de la cuestión de la verdad, es la crisis del sentido. El postulado de la fragmentariedad del saber, que hoy se formula en diversos discursos filosóficos, "hace difícil e inútil la búsqueda de un sentido" (13). Entre tanto dato, información y opiniones, muchos se preguntan si tiene sentido la pregunta por el sentido; nace la duda radical, el escepticismo, la indiferencia, el nihilismo. En este contexto, "una filosofía carente de la cuestión sobre el sentido de la existencia incurriría en el grave peligro de degradar la razón a funciones meramente instrumentales, sin ninguna auténtica pasión por la búsqueda de la verdad" (14).

En este diagnóstico de la cuestión de la verdad, la Fides et ratio identifica algunas corrientes de pensamiento en donde la auténtica búsqueda de la verdad se ha hecho especialmente difícil: En primer lugar el eclecticismo, "término que designa la actitud de quien, en la investigación, en la enseñanza y en la argumentación, incluso teológica, suele adoptar ideas derivadas de diferentes filosofías, sin fijarse en su coherencia o conexión sistemática ni en su contexto histórico" (15). Y otra

(10) Como lo hace el mismo Dalferth, ““Was Gott ist”, bestimme ich!” ...”, art. cit., 421.

(11) Recordemos que en la última encuesta del PNUD - 2001, la creencia en Chile se comporta de la siguiente manera: "creo en Dios a mi manera" = 58\%; "Creo en Dios y participo en una Iglesia" = $33 \%$; "Soy una persona espiritual / mística" = $5 \%$; "No creo en Dios, creo solo en la dignidad del ser humano" = $2 \%$; "Ninguno" = $1 \%$.

(12) Dalferth, "'Was Gott ist", bestimme ich!' ...", art. cit., 426.

(13) Juan Pablo II, Fides et ratio, 81.

(14) Juan Pablo II, Fides et ratio, 81.

(15) Juan Pablo II, Fides et ratio, 86. 
corriente de pensamiento que menciona la Encíclica, que como veremos se asocia con frecuencia a la "hermenéutica", la constituye el historicismo, que niega la verdad perenne de la verdad: "Lo que era verdad en una época, sostiene el historicista, puede no serlo ya en otra" (16). Este historicismo toma la forma de modernismo, cuando en virtud de la actualidad se sacrifica la verdad.

Si solo listáramos todas las corrientes de pensamiento, filosofías, posturas vitales, etc., que hoy -bajos distintos respectos- ponen en cuestión la verdad, inmediatamente percibiríamos la extensión y profundidad que hoy ha alcanzado esta cuestión: el empirismo científico-técnico, el pragmatismo, el historicismo, el relativismo, el nihilismo, el individualismo egocéntrico, el fideísmo, el tradicionalismo, el racionalismo, el integrismo, el fundamentalismo, el fanatismo... Unos niegan la verdad, otros sospechan de ella, otros afirman poseerla... ¿No justifica todo ello la pregunta tipo Pilatos: ¿Y qué es la verdad?

Y, simplemente, para seguir viendo la complejidad de la cuestión en la cultura contemporánea, también habría que atender a los procesos implícitos de afirmación de la verdad, en contextos en que ella explícitamente se niega o se coloca bajo sospecha, como, por ejemplo, sucede con la cuestión de la "normatividad de lo público". Como lo percibe Dalferth, el mismo proyecto de la modernidad pareciera encontrarse aquí con una aporía. Por una parte, él vive de un concepto normativo de lo público (de una razón pública, del common sense, de la responsabilidad ante el bien común), pero, por otra, el mismo proyecto de la ilustración desató un proceso de ideologización de lo público, en el que cada expresión fáctica de lo público se reconoció como "opinión pública" o se idealizó como "comunidad de conversación" y se estilizó como instancia normativa. Sin embargo, advierte Dalferth, "lo fáctico no es lo razonable, la opinión pública no es el barómetro de la verdad, correcto no es aquello que parece ser aceptado por la mayoría, y racional no es solo aquello que siempre, en todas partes y por todos es sostenido con los mismos argumentos. Por ello la apelación a lo público es pseudocrítica cuando solo se sostiene por la actual opinión de la mayoría; es abstracta, cuando apela de modo indeterminado al foro de lo que todos piensan; y es retórica, cuando cada cual solo se hace responsable de sí mismo" (17). ¿Implícitamente, como supuesto de toda normatividad general, no se vuelve a afirmar la verdad? ¿Y qué sucede con el consenso? ¿El mismo no aspira a la afirmación de la unidad de la pluralidad? ¿Y qué sucede con toda explicación que quiera establecerse como teoría general de la sociedad, de la cultura, del mundo, o de lo que sea?

A lo largo de este seminario hemos tenido la oportunidad de reflexionar acerca de diversas comprensiones filosóficas y teológicas de la hermenéutica y nos hemos preguntado por el impacto que ellas han tenido en algunas de las disciplinas teológicas. Consideramos que una de las cuestiones que han estado permanentemente presentes, tanto en las exposiciones como en el debate, es precisamente ese complejo de problemas, preguntas, desafíos, temores, que hoy se han levantado en torno a la cuestión de la verdad: a nuestras posibilidades de conocerla y de comunicarla a otros. Es en este contexto general de la pregunta por la verdad donde queremos

(16) Juan Pablo II, Fides et ratio, 87.

(17) Cf. I.-U., Dalferth, “'Was Gott ist”, bestimme ich!' ..,", art. cit., 419. 
situar las reflexiones que a continuación se siguen. A través de ellas queremos esclarecer las posibilidades de una comprensión teológica de la verdad que, siendo consecuente con las reglas internas de su elaboración, a su vez, dé cuenta de los principales aportes de la filosofía hermenéutica, los cuales los hemos reconocido, principalmente, en dos cuestiones que tienen un carácter fundamental, tanto para la teología como para la filosofía hermenéutica: el lenguaje (punto 3.) y la tradición (punto 4.). Ambas cuestiones las situaremos al centro de la comprensión que la hermenéutica (punto 1.) y la teología (punto 2.) tienen de la verdad.

\section{LA HERMENÉUTICA Y LA CUESTIÓN DE LA VERDAD}

\subsection{La universalización de la hermenéutica}

Aunque el concepto de hermenéutica hunde sus raíces en los mismos orígenes del pensar filosófico, donde la ermeneia ya comprende tanto la expresión, como la explicación y, sobre todo, la interpretación de un pensamiento (18), pareciera que sus antecedentes más próximos se han de reconocer en un proceso histórico de "antítesis a una antítesis" (19), en el que aquellas primeras instrucciones de carácter metodológico, especialmente a partir del siglo XVII, comienzan a constituir la ciencia o el arte de la interpretación (20). Desde entonces, y hasta finales del siglo XIX, la hermenéutica procurará ofrecer las reglas de la correcta interpretación. Su propósito será de índole preferentemente normativo e incluso técnico, limitándose a dar instrucciones metodológicas a las ciencias específicamente interpretativas para prevenir la arbitrariedad en el campo exegético. De este modo, desde el Renacimiento surge una hermenéutica teológica (hermenéutica sacra), una filosófica (hermenéutica profana) y una hermenéutica jurídica. Sin embargo, en un sentido más restrictivo y propio, la hermenéutica filosófica va a designar -principalmente- la posición filosófica de Hans-Georg Gadamer (21), cuyo antecedente más directo lo constituye

(18) En Platón (Theat., 209 A): "la razón [de lo dicho] era la explicación (ermeneia) de la diferencia".

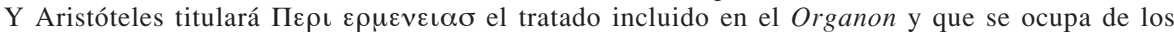
juicios y proposiciones. Cf. J.Ferrater Mora, Diccionario de Filosofía, vol. 2, Alianza, Madrid $51986,1493$.

(19) Verweyen habla de "Antithese zu einer Antithese": así como la ilustración surgiría como una antítesis al positivismo expresado en la paz de Augsburg (cuius regio eius religio), el desarrollo de la filosofía hermenéutica representaría una antítesis de la ilustración, por cuanto en ella se podrían ahora expresar las múltiples fuerzas del espíritu que habían sido desterradas por el ejercicio práctico de la razón pura, y que estaban latentes en las comprensiones más vitales de la historia de pensadores como Hamann y Herder y en las manifestaciones del romanticismo. Cf. H.Verweyen, Gottes letztes Wort. Grundriss der Fundamentaltheologie, Friedrich Pustet, Regensburg ${ }^{4} 2002,58$.

(20) J.Grondin, Introducción a la hermenéutica filosófica, Herder, Barcelona 1999, 19. Una "prehistoria de la hermenéutica se puede leer en este mismo libro de Grondin, pp. 41-77. Este mismo autor ofrece una detallada bibliografía sobre hermenéutica (pp. 203-265), que ordena por obras de consulta general, etapas de la historia de la hermenéutica, la hermenéutica filosófica del siglo XX, y campos de aplicación de la hermenéutica.

(21) Loc. cit. A favor de este sentido restrictivo hablaría la carta de M. Heidegger a Otto Pöggeler en la que afirma: "La filosofía hermenéutica es asunto de Gadamer" (cf. O. Pöggeler, Heidegger und die hermeneutische Philosophie, Freiburg-München 1983, 395; citado por J. Grondin, La filosofía hermenéutica..., op. cit., 19). 
el pensamiento de M. Heidegger, pero, más remotamente, también los enfoques de Schleiermacher, Droysen y Dilthey.

Aunque no corresponda hacer aquí una historia de la hermenéutica, menos aún reconstruir una historia teleológica de ella, como lo ha hecho Dilthey y el mismo Gadamer (22), consideramos necesario identificar algunas de sus principales expresiones, a fin de establecer mejor cómo ella ha representado un desafío para el pensamiento teológico y, en particular, para su comprensión de la verdad.

Pareciera haber acuerdo en situar el siglo XVII, como el inicio de un proceso de universalización de la hermenéutica, en el que autores como J. Dannhauer, G.F. Meier y J.M. Chladenius comprendieron la hermenéutica como el arte general de la interpretación, es decir, en forma germinal, como una hermenéutica universal dentro del espíritu racionalista. Estas doctrinas generales de la interpretación rompieron el marco de las hermenéuticas especializadas, o sea, de las doctrinas técnicas destinadas específicamente a las Sagradas Escrituras o a los autores de la antigüedad clásica" (23).

Sin embargo, será recién Dilthey (1833-1911) quien expresará por primera vez -a partir de las ideas de Boekh y de Schleiermacher- las posibilidades de una hermenéutica universal. Efectivamente, a los 27 años de edad, Dilthey escribió ya un trabajo que tituló Das hermeneutische System Schleiermachers in der Auseinandersetzung mit der älteren protestantischen Hermeneutik. Aunque por este escrito fuera galardoneado con un premio de la Fundación Schleiermacher, el mismo Dilthey no lo publicó y sus ideas principales las recogió solo cuarenta años después, en un texto del año 1900, que fue publicado también póstumamente, trece años después de su muerte. En este texto, Dilthey formula por primera vez la idea de que la hermenéutica tiene por función elaborar las reglas generales de la interpretación, que podrían estar a la base de todas las ciencias del espíritu, ya que todas ellas se apoyan en un conocimiento interpretativo. De este modo, Dilthey insinúa que la hermenéutica podría adquirir una función fundante para las ciencias de la comprensión, a modo de garantía de su pretensión de validez general.

Pero como ya se ha dicho antes en este Seminario (A. Vigo, M. De la Maza), aquella universalidad que en Dilthey se extendía a todas las ciencias del espíritu, en Martin Heidegger (1889-1976) alcanzaría una universalidad aún mayor por cuanto

(22) Como demuestra J. Grondin, es posible presentar la historia de la hermenéutica a modo de un proceso teleológico, como lo ha hecho Dilthey y el mismo Gadamer: "En la antigüedad y la patrística solo se habrían conocido reglas hermenéuticas fragmentarias, hasta que la Reforma de Lutero provocó el desarrollo de una hermenéutica sistemática, que sin embargo solo con Schleiermacher se habría convertido en universal en tanto arte general del entender; posteriormente, Dilthey habría ampliado esta hermenéutica a una metodología general de las ciencias del espíritu y, a continuación, Heidegger ubicaría el planteamiento hermenéutico en el suelo aún más fundamental de la facticidad humana; la hermenéutica universal derivada de esta habría sido elaborada finalmente por Gadamer en forma de una teoría de la condición histórica y lingüística omnipresente en nuestra experiencia. A partir de esta hermenéutica, entendida como universal, se habrían producido continuaciones críticas ulteriores en la crítica a la ideología, la teoría literaria, la teoría de las ciencias y la filosofía práctica" (Cf. J.Grondin, Introducción a la hermenéutica filosófica, Herder, Barcelona 1999, 21).

(23) J. Grondin, Introducción a la hermenéutica filosófica, Herder, Barcelona 1999, 22-23. En este sentido, explica Grondin, debe comprenderse el trabajo del colaborador de Lutero, Flacius Illyricus: se trata de la primera teoría hermenéutica, pero aplicada a la Sagrada Escritura. 
esta, ahora, se extendería a la experiencia del sentido, a las raíces de la existencia, a la cuestión de la verdad. En efecto, antecedido por la interpretación de Georg Misch, Heidegger reconocerá en el pensamiento de Dilthey una filosofía no positivista y abierta a la facticidad histórica de la vida (24), perspectiva que lo llevó a formular una hermenéutica de la facticidad. En Ser y tiempo Heidegger expondrá por primera vez, de modo público, su comprensión de la hermenéutica, pero lo haría de modo muy sucinto. A la definición sistemática y a la ubicación de la hermenéutica dentro de su propuesta de una ontología fenomenológica solo le dedicó una página (25), en la que establece las siguientes tres proposiciones: que "el sentido metódico de la descripción es interpretación"; que "El logos de la filosofía de la existencia (Da-

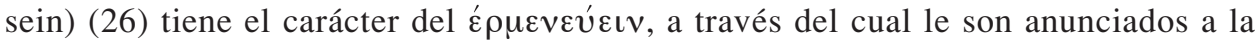
comprensión del ser que es propia de la existencia misma el auténtico sentido del ser y las estructuras fundamentales de su propio ser"; y que la hermenéutica tiene un significado primario de una "analítica de la existenciaridad de la existencia (27). De este modo, como afirma Grondin, con el paso del tiempo la analítica de la existencia, la hermenéutica de la facticidad y la ontología del ser-ahí (Dasein) podían funcionar como sinónimos vagos de lo que ofrecía Ser y tiempo. En textos como Unterwegs zur Sprache Heidegger aclarará que "la hermenéutica no es una dirección dentro de la fenomenología, ni tampoco algo sobrepuesto a ella: es un modo de pensar "originariamente" la esencia de la fenomenología, y, en general, un modo de pensar "originariamente" (mediante una teoría y una metodología) todo lo "dicho" en un "decir" (28). Por ello, pareciera que para una comprensión de la hermenéutica en Heidegger, más importante que su obra Ser y tiempo es su temprano programa de una hermenéutica de la facticidad, que fue el que inspiró a Gadamer.

A Hans-Georg Gadamer se le reconoce el mérito de sacar las consecuencias de la concepción de la historia del ser planteadas por Heidegger para la comprensión tanto de la conciencia históricamente situada como de las ciencias del espíritu que en dicha conciencia se expresó (29). Según el mismo Gadamer, la hermenéutica alcanzó una "auténtica universalidad" solo cuando la psicología descriptiva de Dilthey entró en contacto con la femenomenología, primero de Husserl y luego de Heidegger. Hasta entonces, la hermenéutica se circunscribía a la lógica de la oración (Aristóteles), o bien, a disciplinas especiales, como la hermenéutica jurídica o la hermenéutica teológica (edad moderna). Recién cuando "la era de la metafísica se acercó a su fin y su pretensión de monopolio frente a las ciencias modernas quedó restringido", la hermenéutica comienza a extenderse a la ciencias del espíritu en su conjunto y el entender ya no queda meramente situado al lado del comprender y del

(24) Cf. M. Heidegger, Sein und Zeit, § 77, Max Niemeyer Verlag, Tübingen 1979,

(25) Cf. M. Heidegger, Sein und Zeit, Max Niemeyer Verlag, Tübingen 1979, 37-38.

(26) La expresión Dasein la traduciremos como "existencia". Las razones que da J.E. Rivera para no traducir esta palabra, pensamos que son atendibles; sin embargo, al traducirla por "existencia" se opta por un sentido literal, como él lo reconoce. Cf. J.E.Rivera, "Notas del traductor", en: M. Heidegger, Ser y tiempo (traducción, prólogo y notas de J.E. Rivera), Editorial Universitaria, Santiago 1977, 464.

(27) M. Heidegger, Sein und Zeit, Max Niemeyer Verlag, Tübingen 1979, 37.

(28) Cf. J. Ferrater Mora, "Hermenéutica", en: Diccionario de filosofía, t. 2, Editorial Alianza, Madrid $61986,1495$.

(29) Cf. J.Grondin, Introducción a la hermenéutica filosófica, Herder, Barcelona 1999, 29. 
aclarar. Al contrario, a partir de entonces, afirma Gadammer, "el entender constituye la estructura fundamental de la existencia humana, por lo que viene a situarse en el centro de la filosofía. De este modo pierden su primacía la subjetividad y la autoconciencia, que en Husserl todavía encuentran expresión en el ego trascendental. En su lugar se sitúa el otro, que ya no es objeto para el sujeto, sino que este se halla en una relación de intercambio lingüístico y vivencial con el otro" (30). Es en este "diálogo interior" donde la hermenéutica encuentra su fundamento, donde ella alcanza su auténtica universalidad. Explicando esta afirmación a Jean Grondin, Gadammer afirma que, efectivamente, "la universalidad se encuentra en el lenguaje interior, en el hecho de que no se pueda decir todo. No se puede expresar todo lo que

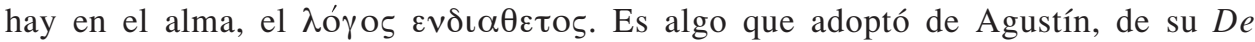
Trinitate. Esta experiencia es universal: el actus signatus nunca se recubre con el actus exercitus" (31). Es en este verbum interius donde reconocemos la propia vitalidad y densidad del lenguaje y donde asumimos "la experiencia de que nuestro hablar depende de palabras previas para poder expresar un sentido que no puede agotarse en los signos disponibles" (32).

De este modo, podemos reconocer que la cuestión de la verdad se encuentra en el núcleo mismo del proceso de universalización de la hermenéutica: sea como condición de posibilidad para una adecuada interpretación de textos clásicos (siglo XVII), como regla general de la interpretación en todas las ciencias del espíritu (Dilthey); como logos de la filosofía de la existencia (Heidegger); o como diálogo interior, donde el intercambio lingüístico y vivencial con el otro supera la relación sujeto-objeto (Gadamer). Por tanto, para la filosofía hermenéutica la cuestión de la verdad no es uno de los tantos temas filosóficos de los que ella pudiera tratar, sino que se desarrolla y constituye como un intento por responder a las preguntas por sus condiciones y posibilidades.

Ahora bien, ¿cómo se plantea ya más específicamente la cuestión de la verdad en la filosofía hermenéutica? A esta cuestión queremos responder en las siguientes reflexiones.

\subsection{La cuestión de la verdad en la hermenéutica}

En el pensamiento filosófico en general, y en la filosofía hermenéutica en particular, la pregunta por la verdad ha estado fuertemente condicionada por la cuestión de su universalidad, sin que hasta ahora, según Grondin, se haya alcanzado claridad al respecto. Pareciera ser relativamente fácil poner a la misma hermenéutica en una contradicción lógica o pragmática: si todo está históricamente condicionado a la interpretación, o, si se quiere, a los intercambios lingüísticos y vivenciales que se verifican en la historia como interpretación, entonces también lo está esta misma afirmación y, por tanto, ella ya no podría pretender una validez universal. Sin embargo, desde la filosofía hermenéutica -Heidegger y Gadamer- se objetará la misma

(30) H.G.Gadammer, "Prólogo", en: J. Grondin, Introducción a la hermenéutica filosófica, Herder, Barcelona 1999, 12.

(31) J. Grondin, Introducción a la hermenéutica filosófica, Herder, Barcelona 1999, 15.

(32) J. Grondin, Introducción a la hermenéutica filosófica, Herder, Barcelona 1999, 196. 
validez de este recurso a la lógica formal, por cuanto con ello se pretende superar engañosamente la propia historicidad de la argumentación formal (33). Ya desde Hegel la cuestión de la historicidad universal se constituyó en un tema central de la filosofía; pero, más allá de ella, desde las distintas manifestaciones del espíritu humano se comenzó a prestar atención a la dimensión histórica de la conciencia y de la vida de los hombres (34). Lo histórico de la historia suscitaría la posibilidad de articular un sistema, pero luego el mismo sistema quedaba sometido a lo histórico y, así, terminaba siendo sobrepasado por el poder que lo había impulsado. Por esta misma razón, escribe B.Welte, “después de los grandes pensadores de Tübingen, ya no fueron nuevamente posibles los sistemas en la filosofía ni en la teología. Y, quizás, con ello se relaciona el hecho de que la superación de la historicidad de la historia se haya convertido en un tema central de la filosofía, aunque ya no más sobre las antiguas bases sistemáticas. Las ideas de Dilthey y luego de Heidegger constituyen un testimonio significativo de ello" (35).

El dilema que se levanta con la cuestión de la historicidad universal -como lo expresa Grondin- "es la pregunta por una verdad vinculante y con ello por una filosofía concluyente dentro del horizonte de un mundo como histórico. ¿Dependen todas las verdades o máximas de la acción de su contexto histórico? Si fuese cierto estaría al acecho el fantasma del relativismo o del nihilismo [...] Si el horizonte cultural ha de ser determinante para la vida, ¿cómo se puede diferenciar o criticar una constelación perversa de vida frente a otra que no lo es? El planteamiento metafísico del historismo, sin embargo, sugiere encontrar la solución de este problema proclamando que se trata de trascender la historicidad. Esto se lleva a cabo, por ejemplo, apelando a una autoridad supratemporal de tipo secular o sagrado, que debiera proclamar la validez de normas que han de ser ahistóricas, o bien recurriendo a la intrascendibilidad de lo lógico y ocasionalmente por medio de la aseveración de la propia condición de fundamentación última. Estas tentativas comparten con el historismo la construcción común de un frente metafísico, a saber, la idea de que todo es perdidamente relativo cuando no se posee una verdad absoluta. Pero, a fin de cuentas, estas soluciones, a su vez, son alcanzadas por el historismo: también de ellas puede demostrarse que siguen estando históricamente condicionadas, puesto que son constantemente superadas y puestas en evidencia en su perspectividad correspondiente" (36).

(33) Según Heidegger este "este tipo de argumentaciones lógico-formales se muestran como "intentos de golpe de mano’, que pretenden superar engañosamente la propia historicidad con ayuda de la lógica. Siguiendo las reflexiones de Heidegger, Gadamer diagnosticó en este punto una 'apariencia formal' que pasa de largo la verdad objetiva. "Es un argumento irrefutable que la tesis del escepticismo o del relativismo, al pretender ser ella misma verdadera, se anula a sí misma. Pero ¿se consigue algo con ello? El argumento de la reflexividad, que así saldría victorioso, más bien repercute en el argumentador mismo volviendo sospechoso el valor de verdad de la reflexión. Lo que queda afectado de esta manera no es la realidad del escepticismo o del relativismo anulador de toda verdad, sino la pretensión de verdad de la argumentación formal en general"' (J.Grondin, Introducción a la hermenéutica filosófica, Herder, Barcelona 1999, 32).

(34) Cf. B.Welte, Geschichtlichkeit und Offenbarung, 22 y ss.; B.Welte, Wahrheit und Geschichtlichkeit (editado por I.Feige), Knecht, Frankfurt am Main, 127 y ss.; 170 y ss.

(35) B.Welte, "Zum Systemgedanken in der Tübinger katholischen Schule", 256. Cf. B.Welte, "Heidegger und die Theologie. Zum 75. Geburtstag von Martin Heidegger”, Der christlicher Sonntag 16 (1964) 310-311.

(36) J. Grondin, Introducción a la hermenéutica filosófica, Herder, Barcelona 1999, 33. 
Sobre el suelo de esta historicidad universal, desde las posibilidades que ella ha generado para la conciencia de ser en el mundo, pero también desde sus propias contradicciones y aporías, se levanta la hermenéutica como problema universal. La hermenéutica alcanza el estatuto de una prima philosophia en nuestro tiempo, probablemente, por "la virtual omnipresencia del fenómeno interpretativo, que está en el orden del día de la filosofía a más tardar desde que Nietzsche se percató del perspectivismo universal ('no hay factos, sino solo interpretaciones'). Nietzsche es tal vez el primer filósofo moderno que sensibilizó la conciencia para percibir el carácter fundamentalmente interpretativo de nuestra experiencia del mundo. Lejos de limitarse a las ciencias puramente interpretativas, como la exégesis, la filología o el derecho, el horizonte de la interpretación se extiende a todas las ciencias y modos de orientación de la vida" (37). Paul Ricoeur considerará que Nietzsche -junto a Freud y a Marx- es uno de los mejores exponentes de la "hermenéutica de la sospecha", por cuanto despliega una estrategia de interpretación que, desconfiando de los sentidos inmediatos, se pregunta expresamente por la voluntad de poder que en ellos se manifiesta. A este hermenéutica de la sospecha, como ya se ha expuesto en este Seminario, Ricoeur contrapone una "hermenéutica de la confianza", la que, sin exponerse ingenuamente a los sentidos inmediatos y buscando desenmascarar la ilusión de la falsa conciencia, deja plenamente abierta la cuestión del sentido que hay que interpretar. Así, en Ricoeur, la conciencia hermenéutica "se dirige con una confianza crítica hacia las posibilidades de descifrar el sentido de las pretensiones de verdad, es decir, hacia verbum interius detrás de cualquier sentido expresado. Esta confianza en el sentido -explica Grondin-, sin la cual el lenguaje carecería de importancia, puede a su vez pretender ser universal. De este modo la hermenéutica de la sospecha resulta serle subordinada en la medida en que su destrucción siempre tiene que llevarse a cabo con respecto a una conciencia 'verdadera', aunque solo actúe como idea reguladora. Una desconstrucción sin la perspectiva al menos de una conciencia menos falsa sería inoperativa" (38).

En este mismo sentido, compartimos la idea de H.-M. Baumgartner, para quien la historicidad del conocimiento y del lenguaje, sin embargo, no debieran comprenderse en relación a la estructura misma de la verdad, sino a su comprensión de la verdad. Bajo este respecto, puede seguir siendo válida la definición clásica: veritas est adaequatio rei et intellectus. "Esta definición es de carácter formal y de allí que no sea una mera determinación nominal ni tampoco una fórmula de garantía de la verdad del conocimiento humano. Se podría reformular del siguiente modo: Si hay verdad, esta adquiere su forma definitiva cuando una cosa (la realidad) es representada por la razón tal como ella es en sí misma. La estructura de la verdad comprende, por tanto, una relación entre dos magnitudes diferentes: la cosa y la razón. Pero esta relación es una relación al interior del lenguaje y de la razón. Esta relación tiene sentido cuando la cosa que forma parte de dicha relación no solo es delimitable, sino que también cuando ella se manifiesta, aunque sea en un sentido rudimentario. Pero, justamente, esto significa que a la estructura de la verdad pertenece la

(37) J. Grondin, Introducción a la hermenéutica filosófica, Herder, Barcelona 1999, 35.

(38) J. Grondin, Introducción a la hermenéutica filosófica, Herder, Barcelona 1999, 38-39 (el subrayado es nuestro). 
apertura de la realidad, como momento fundamental de ella; en dicción clásica: la verdad trascendental. Tomás de Aquino nombra aquello en su famosa colección de definiciones (De veritate I, 1) como aquel momento, in quo verum fundatur, e introduce aquí la definición de Agustín tomada de Soliloquia II: verum est id quod est; donde la verdad se funda en aquello que es. También podríamos decir: la realidad es siempre y necesariamente manifiesta y presente en el horizonte del lenguaje y del conocimiento. Ella es lingüísticamente interpretada y, así, percibida" (39).

Efectivamente el concepto de "verdad" lo hemos entendido -según J.E. Rivera, impelidos por una larga tradición que se remonta al mismísimo Platón-, "como una rectitud o derechura: la rectitud o derechura de un lenguaje que 'acierta' medio a medio en las cosas. Verdad es la cualidad de un decir que no se pierde en circunloquios ni en expediciones por los alrededores, sino que se dirige derechamente a las cosas mismas y da en ellas como la bala en el blanco de la puntería. Verdad es cualidad de aquella inteligencia que acierta medio a medio en la cosa pensada. Verdad es adecuación del intelecto con las cosas, adequatio intellectus et rei, como se decía en la edad media y se sigue diciendo -traducido- todavía hoy" (40). En lugar de adaequatio, aparecen a menudo términos paralelos como correspondentia, conformitas, convenientia, etc.

Por cierto, esta comprensión de la verdad, como adequatio, vale para muchas de nuestras afirmaciones, pero la cuestión es cómo se entiende esa "adecuación", que, en definitiva es relación, como lo ha explicado Heidegger en el conocido $\S 44$ de Ser y Tiempo. La filosofía hermenéutica, directamente influenciada por Heidegger, recurrirá al concepto griego de alétheia (41), para comprender "la verdad" como des-ocultamiento, mostración, aparición. De este modo, la verdad no será tanto una propiedad de la proposición o de la inteligencia (42), cuanto aquello que acontece a las cosas mismas cuando sacadas de su olvido y ocultamiento, cuando son puestas a la luz. Así, "verdad significa ahora no algo que ya está hecho y conseguido: la concordancia de nuestra inteligencia con las cosas. Sino que verdad es algo que se está haciendo en todo momento. Verdad significa ahora aconteci-

(39) H.-M. Baumgartner, "Wahrheit/Gewissheit", art. cit., 269-269.

(40) J.E.Rivera, “Arte y verdad", en: C. Franken (ed.), Verdad e imaginación en la filosofía, teología historia y literatura, Ediciones Universidad Católica de Chile, Santiago 2000, 19. En Santo Tomás de Aquino: "veritas est adaequatio rei et intellectus" (cf. De Ver. q. 1a. 1; Summa Theologica I, q. 16, a. 2 ad 2).

(41) Como explica J.E. Rivera, "alétheia es una palabra compuesta que consta de un prefijo y de una terminación. Prefijo: $a$. Terminación: létheia. A es el signo de una negación; a-tonal quiere decir sin tonalidad; a-pático significa sin pathos, sin sentimientos. A-létheia es también algo "sin". ¿Sin qué? Sin léthe, sin olvido, sin ocultamiento. Alethés singnifica en griego lo que ha sido arrebatado al ocultamiento, lo que ha sido puesto en la luz, en lo abierto. Alétheia es desocultamiento, mostración, aparición" (J.E. Rivera, "Arte y verdad", en: C. Franken (ed.), Verdad e imaginación en la filosofía, teología historia y literatura, Ediciones Universidad Católica de Chile, Santiago 2000, 20).

(42) Para Heidegger, "Die Möglichkeit der Wahrheit menschlicher Erkenntnis gründet, wenn alles Seiende ein "geschöpfliches" ist, darin, dass Sache und Satz in gleicher Weise ideegerecht und deshalb aus der Einheit des götlichen Schöpfungsplanes aufeinander zugerichtet sind. Die veritas als adaequatio rei (creandae) ad intellectum (divinum) gibt die Gewähr für die veritas als adaequatio intellectus (humani) ad rem (creatam). Veritas meint im Wesen überall die convenientia, das Übereinkommen des Seienden unter sich als eines geschaffenen mit dem Schöpfer, ein "Stimmen" nach der Bestimmung der Schöpfungsordnung" (M.Heidegger, Vom Wesen der Wahrheit; en: M.Heidegger, Wegmarken, Vittorio Klostermann, Frankfurt a.M. ${ }^{2}$ 1978, 178). 
miento, algo que ocurre, algo que está pasando. Y acontecer es pura y continuada novedad. Es el devenir de lo que no era. Es prolongada zozobra e inesperado resurgir, es -exactamente- lo que veía Heráclito por debajo de todas las cosas y que él llamaba el fuego, el pûr, la llama que nace de sí misma y vuelve sobre sí, la llama que existe muriendo y a la vez renaciendo" (43). En esta perspectiva, entonces, la verdad no es la sola "derechura" o la "verdad-adecuación"; no es una especia de "cosa" ya hecha y lograda, no es el atributo posible de las proposiciones formuladas por las ciencias y otros saberes. Verdad, más bien, es verdad-acontecimiento, es sacar algo de su olvido, de su ocultamiento, y hacerlo pre-sentarse en su ser mismo, "en su ser verdadero".

A nuestro entender, el desarrollo de la conciencia hermenéutica, en lugar de cerrar o desechar la cuestión de la verdad, lo que ha hecho es mostrar cómo en ella opera una fuerza inclaudicable de infinitud. Y ello no sucede fuera de la conciencia hermenéutica y de su ejercicio práctico, sino como "verbo interior": opera en la historia, que mucho más que una magnitud del pasado, se muestra como la realidad que somete toda verdad a una finitud-infinitud del tiempo; opera como crítica de lo sabido, de lo pensado, de lo conseguido como verdad, desentrañando en todo ello el "interés" que mueve cada una de nuestras representaciones de la verdad y de sus prácticas consecuentes. Pero esta fuerza operante se despliega, principalmente, como confianza: confianza en las posibilidades del lenguaje para expresar aquello que es, o que no es; como confianza para alcanzar conocimientos de esto o de aquello; como confianza para alcanzar consensos, para postular interpretaciones siempre mejores, etc. La conciencia hermenéutica se sigue nutriendo de sus raíces históricas, en donde el postulado mismo de la historicidad universal la obliga a comprender la verdad no simplemente como lo dado, sino como aquello que se manifiesta de muchos modos en una historia abierta al futuro. ¿Qué es si no aquello que se manifiesta en la "historicidad", en el interés, en la confianza, o en la misma esperanza? ¿No es una radical apertura al futuro, pero que, como apertura, solo puede implicar una apuesta? En efecto, la apuesta al futuro no solo es aquello que fundamenta y hace posible nuestra existencia en el mundo, sino que es la dynamis que opera en la conciencia hermenéutica. En cuanto tal, ella no asegura nada, pero lo posibilita todo; ella tiene raíces en nuestra existencia pasada y presente, pero no se deduce mecánicamente de nuestra historia; ella le otorga sentido a todos nuestros intereses, pero siempre en la esperanza; ella incluso sabe que puede ser defraudada en esa esperanza, pero, por ello, sigue siendo aquello que es: una apuesta (44). En este sentido, con Welte podemos afirmar que "en el principio no están ni la acción ni el saber. En el principio está la fe" (45).

Esta dynamis que opera en la conciencia hermenéutica, y en la que se manifiesta la apertura de la verdad, su ser trascendental, no debe entenderse como una mera negación de la finitud, por cuanto es en la misma finitud donde ella se manifiesta y se hace posible para nosotros. En este sentido, podría establecerse

(43) J.E. Rivera, “Arte y verdad”, en: C. Franken (ed.), Verdad e imaginación en la filosofía, teología historia y literatura, Ediciones Universidad Católica de Chile, Santiago 2000, 21-22.

(44) Cf. J. Werbick, Den Glauben verantworten. Eine Fundamentaltheologie, Herder, Freiburg-BaselWien 2000, 76 y ss.

(45) B. Welte, Was ist Glauben?, 25 
una diferencia importante respecto del movimiento fundamental de la metafísica, la cual, según Grondin, "desde el punto de vista etimológico, temático e histórico" se entiende como superación de la temporalidad (46). En la hermenéutica, la infinitud de verdad no reclama la supresión de la temporalidad, sino que, por el contrario, la funda como la única vía de acceso para llegar siempre de nuevo y "de otra manera" a ella.

Por las razones anteriores, sería un malentendido rotular a esta conciencia hermenéutica como un "relativismo nihilista". La misma afirmación de Gadamer, según la cual "no se puede entender mejor, sino solo de otra manera", es justamente una afirmación tanto de la inteligencia como de la verdad y, al mismo tiempo, de las posibilidades de ambas para realizarse en un acto siempre nuevo: en el entender. Así, "entendemos de otra manera porque en cada caso hacemos hablar de nuevo a la verdad cuando aplicamos algo verdadero (una afirmación acertada, una crítica, una opinión plausible) a nuestra situación. Sin duda que hacemos esto en todo momento y cada individuo a su propia y "otra" manera. Todo intento de entender aspira a una verdad sobre la que tal vez se podría discutir, pero sería un error histórico declarar como relativista esta verdad que se capta cada vez de otra manera. Para la hermenéutica, cuando hablaba de él, el relativismo no era más que un fantasma, es decir una construcción hecha para que espante a la gente, pero que no existe. De hecho, nunca se ha definido en serio un relativismo entendido comúnmente como la opinión de que cualquier parecer sobre una cosa o sobre cualquier cosa valga lo mismo, al menos no desde la hermenéutica. Es cierto que la hermenéutica defiende que las experiencias que hacemos con la verdad están implicadas en nuestras situaciones y esto significa: en el diálogo interior que llevamos constantemente con nosotros mismos y con los demás. Pero precisamente por eso no se puede defender un relativismo en el sentido de un anything goes extremo. Nadie está dispuesto a aceptar todo como igualmente válido y legítimo, porque el diálogo interior de nuestra alma, que solo se puede pensar como situacional, se resiste a la contingencia o arbitrariedad de las interpretaciones" (47).

\section{LA VERDAD TEOLÓGICA}

Como propone Verweyen (48), en lugar de eludir el diálogo con esta cultura que se reconoce cada vez más plural y "bajarse del negocio hermenéutico", la teología deberá buscar criterios de orientación en medio de los desafíos que plantea la comprensión hermenéutica de la verdad. Justamente, porque el pensamiento y el lenguaje están inevitablemente condicionados por la historia, se requiere de criterios últimos que los puedan validar como tales. Si ello no sucediera, entonces se haría imposible establecer un discurso racional y responsable respecto de la Palabra de Dios pronunciada de una vez para siempre. Como también lo expresara K. Lehman "la teología

(46) Cf. J. Grondin, Introducción a la hermenéutica filosófica, Herder, Barcelona 1999, 198-199.

(47) J. Grondin, Introducción a la hermenéutica filosófica, Herder, Barcelona 1999, 198-199.

(48) Cf. H. Verweyen, Gottes letztes Wort. Grundriss der Fundamentaltheologie, Friedrich Pustet, Regensburg ${ }^{4} 2002,49$. 
actual no puede dejar de lado la conciencia crítica de la hermenéutica de hoy; pero debe procurar que la pretensión universal y absoluta del cristianismo no desaparezca en una hermenéutica absoluta que todo lo disuelve en devenir histórico" (49).

Como lo hemos dicho al comienzo de estas reflexiones, no pretendemos aquí elaborar una teología de la verdad, sino que establecer algunos "criterios de orientación" que, por una parte, permitan asumir el desafío que plantea la comprensión hermenéutica de la verdad, pero que, a su vez, sea consecuente con la historia de la revelación y de la fe a que ella se debe. Y porque ya en el mismo contexto de la revelación y de la fe neotestamentaria la palabra alétheia en ningún caso es unívoca, sino que, por el contrario, en ella se expresa "todo el espectro de la prehistoria judía y greco-helenística del concepto" (50), aquí tampoco buscaremos un "concepto absoluto" de verdad, menos aún un concepto que simplemente concuerde con aquella verdad que se manifiesta como "luz del ser" en el pensamiento heideggeriano, y luego en la hermenéutica. Ello representaría un concordismo que, aunque a la mano, es necesario evitar (51). Más bien, queremos aquí presentar algunos de los rasgos fundamentales de la verdad, como acontecimiento escatológico del encuentro entre Dios y el hombre. En un primer punto pondremos el acento en la iniciativa de Dios (2.1), luego consideraremos la respuesta del hombre (2.1) y, finalmente, situaremos este encuentro en la dinámica escatológica que en él mismo se manifiesta (2.3).

\subsection{La verdad como acontecimiento de la revelación de Dios}

Se considera que con el libro de Daniel el concepto 'emet, específicamente en su acepción de "verdad", comienza a adquirir un significado nuevo: ser la revelación del designio de Dios (52). El "libro de la verdad" es el libro divino en el que está escrito el proyecto divino para el tiempo de salvación (Dn 10, 21). La "verdad de

(49) K. Lehmann, "Hermenéutica", en: SM III, 400-4008 (citado por H.Waldenfels, Teología fundamental contextual, Sígueme, Salamanca 1994, 91).

(50) H. Waldenfels, Teología fundamental contextual, Sígueme, Salamanca 1994, 466.

(51) Para ello, considérese ya la vasta gama de solo algunos de los empleos y significados que el concepto "verdad" tiene en los escritos neotestamentarios. En efecto, en ocasiones la verdad es sujeto (Jn 1, 17; 8, 32.44; 1 Jn 1, 8; 2, 4; 2 Cor 11, 10; Gal 2, 5; Ef 4, 21) o complemento del nombre (Jn 14, 6;17, 17; 18, 38; $1 \mathrm{Jn} 5,6 ; 2$ Cor 7, 14) y muchas veces acusativo directo de acciones verbales tales como decir, conocer o saber y, en dos importantes ocasiones, de hacer (Jn 3, 21 y 1 Jn 1, 6). También alétheia, sobre todo en Pablo, será atributo de Dios (Rom 1, 25; 3, 7; 15,8), de Cristo (2 Cor 11, 10) y del Evangelio (Gal 2, 5.14; cf Col 1, 5); y determinará el ser del Espíritu (Jn 14, 17; 16, 13; $1 \mathrm{Jn} 4$, 6). En las cartas pastorales $\alpha \lambda \eta ́ \theta \varepsilon \iota \alpha$ adquirirá el sentido de

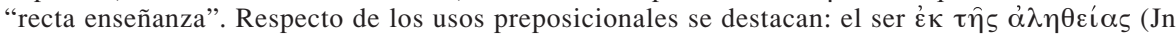

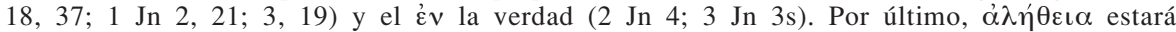

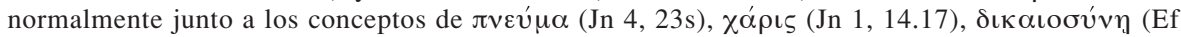

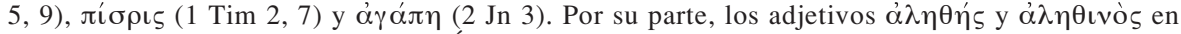
Juan pertenecerán a Dios, en cuanto Él se ha revelado como verdad en el Hijo (Jn 3, 33; 7, 28; 8,

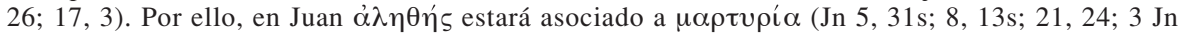
12). En este sentido también será verdadero Cristo (Jn 7, 18; 1 Jn 5, 20; Mc 12, 14; Mt 22, 16), "pan del cielo" (Jn 6, 32), su carne y su sangre (Jn 6, 55). En el libro del Apocalipsis encontramos el adjetivo $\alpha \dot{\lambda} \eta \theta$ uvòs como atributo de Dios (Ap 6, 10), de Cristo (Ap 3, 7.14; 19, 11), de los caminos de Dios (Ap 15, 3), de sus sentencias (Ap 16, 7; 19, 2) y de sus palabras (Ap 19, 9) (Cf. H.Hübner, "Wahrheit", EWNT 1, 138-145).

(52) Así en Dn 8, 26 leemos que "la visión referida de las tardes y mañanas es verdad" ("emet)", puesto que a ella nos podemos confiar, sucederá como se ha dicho (cf. 10, 1 y 11,2). 
Dios" que debe ser reconocida por el justo (Dn 9, 13) es aquella "verdad" que ha sido tirada "por tierra" (Dn 8,12), y representa el conjunto de las tradiciones judías que se han de reconocer y observar. De este modo, en la literatura apocalíptica y sapiencial, la verdad que revela el designio de Dios es también la sabiduría, la doctrina de la salvación, según la cual se deberán regir los hombres (cf Sab 3, 9).

Ya en el sentido de esta tradición sapiencial se nos muestra que la verdad de la fe tiene el carácter de acontecimiento. Esto significa, negativamente hablando, que la verdad de la fe "no es algo así como una reserva atemporal, ni algo así como un valor en sí mismo, ni tampoco, primeramente, una adaequatio intellectus et rei " (53). Más bien, la verdad de la fe es "aquello que sucedió y que sucede, en cuanto acontece como verdad. Esta verdad acontece, en cuanto ella surge desde su propio origen divino y resplandece, iluminando a quien ella alcanza y a quien la acoge" (54). Para Pablo será central denunciar aquella ilusión de "poseer en la ley la norma de la ciencia y de la verdad" (Rom 2, 20); "la verdad de la ley" ha sido sustituida ahora por "la verdad del evangelio (Gal 2, 5.14); "la palabra de la verdad" (Ef 1, 13; cf Col 1, 5; 2 Tim 2, 15) es "el evangelio de vuestra salvación". Como dirá el Vaticano II: "la verdad íntima acerca de Dios y acerca de la salvación humana se nos manifiesta por la revelación en Cristo, que es a un tiempo mediador y plenitud de toda la revelación" (55).

Como acontecimiento, la verdad de la fe está asociada al tiempo y al espacio en donde ella acontece. No es simplemente una verdad abstracta; ella está asociada a una historia que la constituye y conforma internamente. Ciertamente, afirma Welte, "tenemos razones para pensar que en último término hay una sola verdad que todo lo comprende. Sin embargo, desde el momento en que esa verdad es comprendida bajo determinados respectos en ideas, conceptos y palabras, es decir, cuando ella se hace lenguaje, entonces ella aparece en una diversidad de posibilidades y surge el problema de la verdad e historicidad" (56). En su misma historicidad, la verdad de la fe es un acontecimiento personal: es el acontecimiento de Jesús de Nazareth, que acontece en un tiempo y en un lugar determinados, y que, aconteciendo para siempre, es manifestación y testimonio del ser de Dios, es luz para los hombres, es vida entregada, es libertad regalada. Por ello, "en la Biblia se habla menos de lo que es, y, mucho más, se cuenta y se anuncia aquello que sucedió" (57).

Por ello, como afirma I. de la Potterie, citando a un teólogo ortodoxo, "el único punto de partida para una concepción cristiana de la verdad es la cristología" (58). Este es un aspecto, sin duda, destacado muy especialmente por San Juan, para quien la "verdad" es tanto la realidad como la revelación divina. "La revelación divina es, para Juan, necesariamente la verdad, pues de lo contrario no habría revelación. El concepto joánico de verdad toma elementos tanto hebreos del antiguo testamento como griegos, al referirse a lo absolutamente fiable y válido y a lo real y cognoscible al mismo tiempo. La aléthia joánica se define esencialmente por su indisociabi-

(53) B.Welte, "Über den Sinn von Wahrheit im Bereich des Glaubens", en: Zeit und Geheimnis, 287.

(54) B.Welte, "Über den Sinn von Wahrheit im Bereich des Glaubens", en: Zeit und Geheimnis, 287.

(55) Dei Verbum, n. 26.

(56) B.Welte, "Die philosophisch-theologische Problematik", Herderkorrespondenz 34 (1980) 77.

(57) B.Welte, "Die Krisis der dogmatischen Christusaussagen", en: Zeit und Geheimnis, 312.

(58) I.de la Potterie, "Verdad", en: R.Latourelle, R.Fisichella y S.Pié-Ninot, Diccionario de Teología Fundamental, San Pablo 1992, 1613 (cita J.D. Zizioulas). 
lidad de la persona de Jesús, el Revelador. Cuando Jesús afirma a menudo que dice la verdad (Jn 8, 40.45s; 16, 7), la afirmación no significa solo que su palabra es verdadera, sino sobre todo que la revelación se basa radicalmente en Él como su portador. De ese modo la cuestión de la verdad deriva al final en la cuestión de la persona de Jesús mismo. Esto nos da a entender también en Jn 14, 6 una frase de Jesús en la que Él se presenta como camino hacia la realidad que Él mismo es: la fidelidad de Dios en persona, en la que los hombres pueden descansar y asentarse; la autocomunicación radical de Dios, autocomunicación que significa vida” (59).

Esta concentración ontológico-personal del concepto de verdad (60) no puede constituir un hecho insignificante o secundario para la teología, puesto que él impulsa al pensamiento teológico a discernir y a formular la verdad de la fe como apertura y acogida del misterio inefable de Dios, como participación libre en el acontecimiento de Jesucristo en la historia. Ciertamente, la teología no puede producir este acontecimiento; sin embargo, pensando, puede y debe remitir a él, puede y debe ayudar a comprenderlo, puede y debe decirlo para los hombres y mujeres de hoy. Justamente porque "la verdad teológica" no puede "producir" este acontecimiento, ella queda remitida a una realidad que no solo siempre la supera, sino que, más fundamentalmente, solo se le manifiesta en el movimiento mismo de la fe. Por ello, a esta dimensión ontológico-personal de la verdad, corresponde siempre por parte del hombre la fides qua, la acogida del amor gratuito y misericordioso Dios, que, en Cristo, nos invita a participar de la amistad divina (cf Jn 15, 14 y 15).

Sin embargo esta concentración ontológico-personal de la verdad en Cristo, en caso alguno justifica la sola relación afectivo-existencial ( $\mathrm{fe}$ fiducial) con Él. Los mismos textos joánicos recién citados, efectivamente nos hablan de cómo Jesús nos

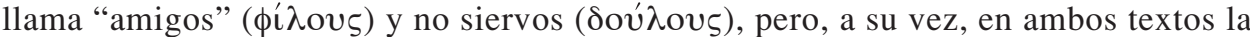
amistad se establece en estrecha relación con el conocimiento de Dios y con el hacer su voluntad (61). La amistad con Cristo no es una mera afección sensorial, sino que,

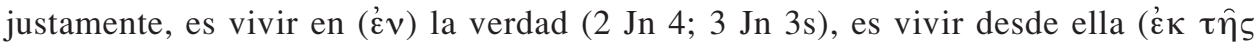
$\alpha \lambda \lambda \eta \varepsilon i \alpha \varsigma)(J n$ 18, 37; 1 Jn 2, 21; 3, 19) (62).

(59) H.Waldenfels, Teología fundamental contextual, Sígueme, Salamanca 1994, 466-467.

(60) Cf. H.Hoping, "Wahrheit und Dogma zwischen Dogmatismus und Relativismus. I. Kritische Überlegungen zum Dogmen- und theologischen Wahrheitsbegriff bei Hans Küng”, Zeitschrift Wissenschaft und Weisheit 46 (1983) 24-26.

(61) La amistad con Jesús conlleva el hacer su voluntad, así como Él mismo ha venido para hacer la voluntad de su Padre: Jn 5, 30 "porque no busco mi voluntad, sino la voluntad del que me envió" Jn 4, 34: "Mi alimento es hacer la voluntad del que me envió y completar su obra"; Jn 6, 38: "pues he bajado del cielo no para hacer mi voluntad, sino la voluntad del que me ha enviado"; 7 , 17 El que quiera hacer la voluntad de Dios conocerá si mi doctrina es de Dios o si hablo por mi cuenta"; Mt 7, 21: "no todo el que dice Señor, Señor..."; Mt 12, 50: "Porque el que hace la voluntad de mi Padre celestial, ese es mi hermano, mi hermana y mi madre"; et passim.

(62) Ya el concepto 'emet indica que la verdad se podrá también ejercer (como lealtad: Gen 47, 29; como fidelidad: Neh 9, 33; como veracidad: 2 Cro 31, 20) y decir (2 Sam 7, 28; 1 Re 17, 24; 22, 16; Jr 9, 4; 43, 9). En este último caso, 'emet no solo tiene el sentido de la credibilidad de quien habla, sino también a la credibilidad de lo dicho, en el entendido de que las palabras son verdaderas en cuanto remiten a lo que es. Esto no implica un proceso de abstracción del concepto de verdad, puesto que en ambos casos - respecto de quien dice, como de lo dicho- lo que está en juego es la posibilidad de remitir de modo firme, seguro, confiable, fiel, a aquello que es. (Cf. H.Wildberger, Art.: ' $m n$, en: E. Jenni-C.Westermann (eds.), Vol I, Chr. Kaiser Verlag-Theologischer Verlag Zürich, ${ }^{4} 1984,201$ y ss.). 
Pero como acontecimiento de salvación, la verdad no solo se identifica con Cristo (Jn 14, 6), sino también con el Espíritu. El Espíritu de Cristo es también el Espíritu de la verdad (cf. Jn 14, 17; 15, 26; 16, 13; 1 Jn 4, 6 y passim). "Cuando llegue Él, el Espíritu de verdad, os guiará hacia la verdad total” (Jn 16, 13). Esta idea tendrá una fuerte presencia en la teología de la revelación del Vaticano II, particularmente en la Dei Verbum, donde "el envío del Espíritu de la verdad", se reconoce como el acontecimiento último de la obra redentora de Cristo (63); "el Espíritu Santo, por quien la voz del Evangelio resuena viva en la Iglesia, y por ella en el mundo, va induciendo a los creyentes en la verdad entera, y hace que la palabra de Cristo habite en ellos abundantemente (cf. Col., 3, 16)" (64). En este breve texto de la Dei Verbum es posible destacar cuatro importantes funciones del Espíritu en relación a la verdad.

En primer lugar, el envío del Espíritu hace posible que el mismo "Evangelio de la verdad" (Gal 2, 5.14; cf Col 1, 5) siga vivo en la Iglesia; que aquel acontecimiento de la salvación de Dios en Cristo no quede anclado en el pasado, sino que viva hoy en su Iglesia; que la Verdad siga siendo el principio vital de la Iglesia.

En segundo lugar, el texto nos indica que esta Verdad viva en la Iglesia, por el envío del Espíritu ahora se comunica a todos los hombres, por medio de ella. Al acontecimiento mismo de la salvación pertenece el don escatológico y universal del Espíritu, de tal manera que ahora el Espíritu de la Verdad no solo abre el futuro escatológico de Dios, sino que, además, según las promesas del Dios fiel (cf J1 3, 15), Él deja de ser la propiedad de un pueblo, de una raza, de una generación, de un género, ...: "Sucederá en los últimos días, dice Dios: Derramaré mi Espíritu sobre todo mortal y profetizarán vuestros hijos y vuestras hijas; vuestros jóvenes verán visiones y vuestros ancianos soñarán sueños. Y también sobre mis siervos y sobre mis siervas derramaré mi Espíritu..." (Hech 2, 17-18). Esta universalidad del acontecimiento de la verdad, Pablo la expresará extraordinariamente, asociando indisolublemente al Espíritu, a Cristo y a la Iglesia: "Los que os habéis bautizado en Cristo os habéis revestido de Cristo: ya no hay judío ni griego; ni esclavo ni libre; ni hombre ni mujer; ya que todos vosotros sois uno en Cristo Jesús" (Gal 3, 27-29).

El tercer aspecto que queremos destacar del texto de la Dei Verbum, nos remite a las palabras y promesas de Jesús: "Cuando llegue él, el Espíritu de verdad, os guiará hacia la verdad total” (Jn 16, 13). Ciertamente, aquí la verdad se manifiesta como un acontecimiento inacabado; aún no estamos en la verdad total; nuestras experiencias, como también nuestras conceptualizaciones y nuestros símbolos, no son expresiones definitivas del acontecimiento de la salvación. Sin embargo, junto con afirmar la provisoriedad de nuestra experiencia de la verdad, podemos confiar en el don del Espíritu que nos guiará hacia la plenitud de la verdad.

El cuarto aspecto del texto en cuestión nos permite determinar mejor en qué consiste ese camino hacia la verdad. Este no queda en una vaga confianza en la posible acción del Espíritu, sino en la configuración con Cristo, en la habitación de su palabra en nosotros. De este modo el Espíritu de la verdad, en cuanto se nos ha enviado por el Padre y el Hijo como don escatológico de la salvación, nos

(63) Dei Verbum, n.4.

(64) Dei Verbum, n.8. Véanse también nn. 9.19.20. 
inserta en el misterio mismo de Cristo, nos hace uno con Él, nos hace partícipes de la vida de Dios.

\subsection{La verdad como acontecimiento de la libertad y del amor}

De las consideraciones anteriores de la verdad como acontecimiento de la revelación de Dios, se sigue otra característica fundamental de verdad, comprendida teológicamente: ella es una acontecimiento que se verifica en su capacidad para transformar nuestra vida y nuestra historia de acuerdo a la voluntad salvífica de Dios. En efecto, el sentido de la verdad de la fe no es construir, por medio de enunciados categoriales, un conjunto ordenado de ideas acerca de Dios, del hombre y del mundo, sino, como decíamos al final del punto anterior, interpelar al hombre para que este participe en el acontecer actual de la verdad, para que se deje transformar por ella, para que viva en ella y desde ella. En el texto de Jn 8, 32 -“y conoceréis la verdad y la verdad os hará libres"-, es posible reconocer un carácter "transitivo" de la verdad hacia la libertad. Y la transitividad de la verdad se verifica en una doble transformación que suscita en quien se abre a ella y la acoge en la fe. Por una parte, la verdad de la fe le revela al hombre aquella verdad que él mismo se esconde y oculta: el pecado. Esto es "conocer la verdad": reconocer el pecado y la culpa en la propia vida y en la vida del mundo. La verdad, en este sentido, revela al hombre su verdad y lo confronta con ella. Pero la verdad de la fe no solo se orienta transitivamente al hombre para de-velarle su verdad, sino que, al mismo tiempo, para conducirlo hacia ella, para llevarlo a la vida y a la libertad. Este acontecimiento de la verdad, es entonces el acontecimiento de la vida y de la libertad, el acontecimiento del amor gratuito y salvífico de Dios. Como escribe Welte, "en este movimiento del poder transformador de la verdad de la fe, la verdad conduce a la libertad [...] La misma verdad es espíritu y vida. Como espíritu ella es fuerza transformadora, renovadora y dadora de vida" (65).

Pero como acontecimiento de salvación, la verdad de la fe no solo se muestra en su transitividad hacia la libertad, sino que desde ella misma también hacia el amor. Llama la atención que en un número significativo de textos veterotestamentarios 'emet -que en 100 de los 127 casos los LXX traducen por alétheia- aparece junto a hésed (amor), indicando que ambos conceptos se encuentran a un mismo nivel y que ambas poseen un peso específico (66). En textos como Os 4, 1 y Mi 7, 20 'emet se encuentra incluso antes que hésed, pero en la mayoría de los casos están unidos por un "y", marcando así la estrecha relación entre ambos, donde 'emet modifica hésed, otorgándole al amor su fidelidad, seguridad y verdad (Sal 25, 10; 40,$12 ; 57,4 ; 85,11 ; 86,15 ; 89,15 ; 138,2$; Gn 24, 27; 32, 11; Ex 34, 6; 2 Sam 2, 6; etc.). Nos parece importante el texto de Oseas 4, 1: "no hay verdad ni amor ni conocimiento en esta tierra". No interesa aquí el "diagnóstico de la realidad", cuanto el hecho que en este texto se establece una relación entre el conocimiento de Dios y

(65) B.Welte, "Über den Sinn von Wahrheit im Bereich des Glaubens", en: Zeit und Geheimnis, 290 y 291

(66) Cf. H.Wildberger, Art.: 'mn, en: E.Jenni-C.Westermann (eds.), Vol I, Chr. Kaiser Verlag-Theologischer Verlag Zürich, ${ }^{4} 1984,201$ y ss. 
la verdad y el amor. El conocimiento de Dios se realiza en la práctica de 'emet y hésed. La continuación de este texto de Oseas deja claro que no se trata de una práctica que se dirija directamente hacia Dios, sino que preferentemente hacia los demás. Y cuando se dirige hacia Dios, ya no se trata del comportamiento de individuos, sino que compromete a todo el pueblo de Israel.

En Cristo la experiencia de vida y libertad que produce el Espíritu es la única que relativiza los demás vínculos y libera de ellos. En este sentido no basta la adhesión de principio al mensaje de Jesús, ni siquiera la solemne declaración de su señorío (Mt 7, 21); se requiere de una fe que opere efectivamente por la caridad (Gal $5,6)$. De allí que Pablo advierta sobre el peligro de tomar la libertad como "pretexto para la carne; antes al contrario, servíos unos a otros por amor. Pues toda la ley alcanza su plenitud en este solo precepto: Amarás a tu prójimo como a ti mismo" (Gal 5, 13-14).

Esta transitividad de la verdad hacia la libertad y hacia el amor, no debe entenderse como un pasar de una cosa a otra, como un dejar algo para alcanzar lo otro. Más bien, en esta transitividad se manifiesta la única fuerza del Espíritu de la verdad, que cuando lo acogemos mediante la fe, nos configura con Cristo y nos permite llamar a Dios Abbá (Gal 4, 6; Rom 8, 15). De este modo, verdad-libertadamor se integran y corresponde en el único movimiento de la fe, posibilitado por la acción del Espíritu. Ya en el AT la expresión 'amén expresará -entre otros- dos significados que "se fundan en la misma dialéctica del concepto" (67). Por una parte, expresará la respuesta creyente a aquello que Dios mismo revela, o hacia aquello que se comunica con su autoridad; en este caso, decir "así sea" será reconocer la verdad y consistencia de aquello se afirma (cf. Dt 2, 7, 15-26; Tob 8, 8). Pero, al mismo tiempo, aquello verdadero se reconoce como "válido" y, por tanto, como algo que involucra y compromete a quien pronuncia el amén $(1 \mathrm{Re} 1$, 36; Jer 15, 11; Neh 8, 6; Sal 41, 14; 72, 19). Por cierto, no se trata de un compromiso voluntarista, por cuanto nuestro amén se funda siempre en el "Dios del amén" (Is 65, 16). Así Pablo podrá confesar que "todas las promesas hechas por Dios han tenido su sí en él; y por eso decimos por él "Amén" a la gloria de Dios"

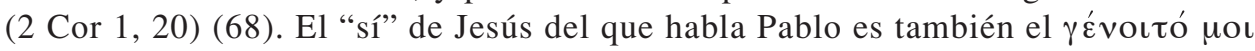

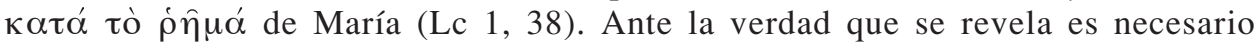
asentir en la libertad de la fe, pero este asentimiento no solo compromete el intelecto, sino como en María, involucra la vida entera. Esta es la expresión histórica más eminente de aquello que sucede cuando, por la gracia del Espíritu, se encuentran la verdad, la libertad y el amor.

Esta comprensión de la verdad como acontecimiento de libertad también la vemos expresada en el Vaticano II, cuando se afirma que, en virtud de la inspiración del Espíritu Santo, "los Libros sagrados enseñan sólidamente, fielmente y sin error la verdad que Dios hizo consignar en dichos libros para salvación nuestra" (69).

(67) Cf. H.Wildberger, Art.: ‘mn, en: E.Jenni-C.Westermann (eds.), Vol I, Chr. Kaiser Verlag-Theologischer Verlag Zürich, ${ }^{4} 1984,194$.

(68) Cf. H.Wildberger, Art.: ' $m n$, en: E.Jenni-C.Westermann (eds.), Vol I, Chr. Kaiser Verlag-Theologischer Verlag Zürich, ${ }^{4} 1984,195$.

(69) Dei Verbum, n. 11. 
Está claro que la verdad de los textos bíblicos no radica en la sola coherencia interna de sus enunciados, ni tampoco en la concordancia de todas sus narraciones con el dato histórico-positivo. La verdad de estos libros, más bien, se debe reconocer en su capacidad para transformar nuestra vida de acuerdo a la voluntad salvífica de Dios (nostrae salutis causa). En el mismo sentido indicado en el párrafo anterior, se puede afirmar que la causa de Dios, nuestra salvación, no acontece sin el hombre. Los mismos textos bíblicos son expresión de cómo la verdad que allí se manifiesta acontece gracias al encuentro de Dios con el hombre, gracias a la acción del Espíritu que hace posible que los hombres puedan ser llamados "verdaderos autores", testigos del acontecimiento de la verdad (70).

\subsection{La verdad como acontecimiento escatológico}

La verdad "teológica" es la verdad y el amor de Dios que se han manifestado de modo pleno y definitivo en Jesucristo. El principio y fundamento de la verdad es Jesucristo, el enviado y testigo del Padre. Su Espíritu es quien asegura la permanencia en la verdad, quien nos guiará a la verdad total. A esta verdad que se nos ha manifestado de modo pleno y definitivo en Cristo, estamos llamados a participar por medio de la fe, la cual hemos comprendido como la transitividad de la verdad hacia la libertad y el amor. Hemos explicado también que no se trata aquí de un movimiento vuelto sobre sí mismo, ni de una circularidad cerrada, sino que, por la naturaleza de cada uno de sus momentos y gracias a la acción del Espíritu que los anima, el queda bajo el influjo de la acción salvífica escatológica, que en palabras de Rahner es la superación de todo "no" siempre posible en el hombre y en su historia (71).

La verdad -bajo este respecto- no se sustenta tanto en nosotros, como en Dios mismo, en su victoria sobre el engaño y la mentira. Pero, si en Dios, también en nosotros, por cuanto nos hace partícipes de su amor, del amor que es verdad y libertad. Se trata de una verdad a la que llegamos y permanecemos por una relación. Y eso es lo que salva: la no circularidad sobre nosotros mismos, sobre nuestras disquisiciones, nuestras autorreferencias, nuestras inseguridades y temores. Concordamos plenamente con Bruno Forte, cuando afirma que "el hombre que se para sintiéndose dueño de la verdad, el hombre para quien la verdad ya no es Alguien que le va poseyendo cada vez más profundamente, sino algo que él aspira a poseer, tal hombre ha borrado en sí mismo no solo a Dios, sino la propia dignidad de ser humano. La condición humana implica la actitud de éxodo; el hombre está saliendo, está llamado permanentemente a salir de sí, a preguntarse, buscando una patria intuida, aunque nunca poseída" (72).

Cuando la verdad se comprende como acontecimiento de la revelación y de la libertad, entonces ella, en ninguno de sus dos momentos, y menos aún en la relación por la que cada uno de ellos se constituye, puede eludir la cuestión de la "apertura hermenéutica". Sin embargo, respecto de esta "apertura hermenéutica de la verdad",

(70) Dei Verbum, n. 11.

(71) Cf. K. Rahner, Curso fundamental sobre la fe, Herder, Barcelona 1979, 437 y ss.

(72) B. Forte, La esencia del cristianismo, Sígueme, Salamanca 2002, 111. 
me parece oportuno considerar dos peligros sobre los cuales Verweyen ha llamado la atención, por cuanto podrían constituir una evasión de la radicalidad que supone la pregunta por la verdad (73). El primero de estos peligros está en el recurso apresurado a la "reserva escatológica". Las experiencias de falibilidad, precariedad, provisoriedad que acompañan toda realización humana, especialmente al pensamiento y al lenguaje, pudieran llevarnos a desconfiar de las capacidades de la razón y a buscar un refugio seguro "en el más allá". Es cierto que Pablo $(1$ Cor 13, 12) da cuenta de la parcialidad de nuestro conocimiento, del carácter velado que posee nuestra actual visión, y afirma que solo "entonces veremos cara a cara", que solo "entonces conoceré como soy conocido". Pero la cuestión está en las consecuencias que sacamos de este importante texto paulino. ¿El postulado de la reserva escatológica no lleva a postergar para "el último día", aquello que con urgencia reclama nuestra inteligencia, tanto de cara a nosotros mismos como de cara a los demás? ¿No es este recurso al "entonces" una escapatoria fácil para eludir las exigencias actuales del pensar? Si la "reserva escatológica" lleva a considerar cada afirmación sobre las posibilidades ya actuales de un conocimiento definitivo y verdadero como una arrogancia de la razón, entonces, efectivamente, ella en poco o nada se diferencia del fideísmo. La apertura hermenéutica, como explica Verweyen, no se constituye "solo "a pesar de Dios" - a causa de la insuficiencia humana para "llevar al concepto" el lenguaje y la historia-, sino finalmente "gracias a Dios", a causa de la insondable libertad humana, que busca expresarse en ese lenguaje e historia" (74).

Cuando la apertura hermenéutica no ha sido reflexionada desde la perspectiva de una filosofía primera, cuestión que trataremos luego, entonces también se corre el peligro de "hipostasiar la apertura del preguntar" (75); cuestión que podría estar expresando M. Heidegger cuando afirma: "Lo determinante de la esencia del hombre no es nunca respuesta, sino esencialmente pregunta" (76). Sin embargo, advierte Verweyen, las verdaderas preguntas encierran siempre la posibilidad de ser superadas por una respuesta. La decisión de dejar por principio las preguntas abiertas no constituye un acto del preguntar, sino que un juicio decidido, respecto del cual es justo levantar sospechas, por cuanto esta decisión pudiera ser una estrategia de inmunización ante el compromiso personal que conlleva el encontrar una respuesta y

(73) H.Verweyen, Gottes letztes Wort. Grundriss der Fundamentaltheologie, Friedrich Pustet, Regensburg ${ }^{4} 2002,64-70$.

(74) H.Verweyen, Gottes letztes Wort. Grundriss der Fundamentaltheologie, Friedrich Pustet, Regensburg ${ }^{4} 2002,62-63$. Véase al respecto la crítica que Verweyen hace a la comprensión de Pannenberg del "carácter anticipatorio del contenido y del acto de la fe". En lo sustantivo, Verweyen considera que la afirmación del carácter anticipatorio -en Pannenberg- difícilmente se escapa al juicio de Hegel sobre la "mala infinitud" (schlechte Unendlichkeit), puesto que al menos se debería dar razón de las condiciones y posibilidades de ese sentido último y definitivo, se debiera poder explicar cómo el creyente conoce responsable y racionalmente su evidencia del sentido último y se debiera distinguir mejor entre la "apertura estructural del discurso" y la pregunta por los fundamentos de legitimación real de aquello que es "discutible", como para Pannenberg lo es la resurrección de los muertos, "la cual dejará de ser discutible, cuando todos hagan la experiencia de que los muertos resucitan" (Cf. H.Verweyen, Gottes letztes Wort. Grundriss der Fundamentaltheologie, Friedrich Pustet, Regensburg ${ }^{4} 2002$, 65-67, particularmente las notas 8 y 10).

(75) H.Verweyen, Gottes letztes Wort. Grundriss der Fundamentaltheologie, Friedrich Pustet, Regensburg ${ }^{4} 2002,68$.

(76) M. Heidegger, Einführung in die Metaphysik, 109 (citado por H.Verweyen, Gottes letztes Wort. Grundriss der Fundamentaltheologie, Friedrich Pustet, Regensburg ${ }^{4} 2002,69$ ). 
tomar posición respecto de ella. Esto sería todo lo contrario a una apertura hermenéutica incondicionada; más bien, expresaría un dogmatismo incuestionado que se refugia en la indeterminación de una supuesta libertad individual. La auténtica apertura hermenéutica se verifica en el preguntar y, muchas veces, en aquel preguntar que desacomoda. El preguntar también es expresión de la libertad. Como bien afirma Welte: "la pregunta no puede marginarse con explicaciones verbales, como la de que carece de sentido seguir preguntando. Contra esto hay que rebelarse siempre; y, de nuevo, mediante la razón: ¿por qué eso no ha de tener sentido? Preguntar siempre es legítimo. La razón tiene que preguntar siempre y comenzar a preguntar siempre de nuevo. Es posible que alguna vez la razón ya no encuentre respuesta para sus preguntas. Pero Dios nos libre de que ella deje de preguntar" (77). Pero, justamente, la razón aquí busca respuestas y no una coraza para esconder el miedo a ejercer la propia libertad. La auténtica postura hermenéutica no está solo en la apertura del preguntar, sino también en la de responder. Para Gadamer, justamente, lo que determina la comprensión como acontecer es una dialéctica: la dialéctica de pregunta y respuesta (78).

\section{LA VERDAD Y EL LENGUAJE}

\subsection{La verdad como acontecimiento del ser en el lenguaje}

Desde la perspectiva de la filosofía hermenéutica la verdad no es solo acontecimiento del ser, sino acontecimiento en el lenguaje. Como explica J.E. Rivera, "es un error inveterado concebir la palabra como un signo sensible de algo inteligible. Al pensarla así, deshacemos la palabra, la momificamos, la matamos. La palabra es un todo indiviso: es, al mismo tiempo, sentir e inteligir, es acontecimiento espiritual. Espiritual no quiere decir alejado del cuerpo, no significa algo meramente mental. Espiritual es también el propio cuerpo cuando queda asumido por el espíritu. San Pablo -nada menos- hablaba de un sôma pneumatikón, de un cuerpo espiritual [...] Toda palabra es una especie de "sentido espiritual", algo así como un trozo de materia sonora en la que irrumpe la plenitud del espíritu, quiero decir, de esa abertura al Ser en que consiste la existencia del hombre" (79).

Según H.-G.Gadamer "el lenguaje es el verdadero centro del ser humano si se contempla en el ámbito que solo él llena: el ámbito de la convivencia humana, el ámbito del entendimiento, del consenso siempre mayor, que es tan imprescindible para la vida humana como el aire que respiramos. El hombre es realmente, como dijo Aristóteles, el ser dotado de lenguaje. Todo lo humano debemos hacerlo pasar por el lenguaje" (80). Para Gadamer el lenguaje es el centro desde el cual se desarrolla la experiencia hermenéutica en tanto que experiencia de la finitud humana

(77) B.Welte, Filosofía de la religión, 88

(78) H.-G. Gadamer, Verdad y método, Sígueme, Salamanca 1991, 565.

(79) J.E. Rivera, "Arte y verdad", en: C. Franken (ed.), Verdad e imaginación en la filosofía, teología historia y literatura, Ediciones Universidad Católica de Chile, Santiago 2000, 25.

(80) H.-G. Gadamer, Verdad y método, vol. II, Sígueme, Salamanca 1992, 152 
abierta al infinito. Como explica Mariano de la Maza, "desde esta perspectiva, la verdad que se experimenta no es primariamente un comportamiento del sujeto, sino un acontecimiento del ser en el lenguaje. Gadamer se distancia tanto de la metafísica griega, que subordina teleológicamente el conocimiento a un orden previamente dado del ser en sí, como al idealismo moderno, que subordina el ser a su constitución por parte de un sujeto cognoscente. Desde el lenguaje como centro se plantea la copertenencia de lo objetivo y de lo subjetivo. Gadamer sigue a Heidegger en su recuperación del concepto originario de la verdad como alétheia, desocultamiento o develamiento del ser, o sea como un acontecimiento en el que el sentido del ser accede al lenguaje [...]. Según esta concepción ya no se puede separar lo que algo es y el modo como se lo representa en el lenguaje, pues la representación lingüística forma parte del modo de ser de todas las cosas [...] la verdad en tanto que manifestación del ser no está dada de un modo fijo, sino que acontece como juegos de lenguaje, en los que la subjetividad del que comprende se ve llevada por un acontecimiento que lo supera y en virtud del cual se hace valer lo que tiene sentido mucho antes de que podamos hacernos cargo de ello mediante un saber reflexivo" (81).

En atención a afirmaciones como las anteriores se puede sostener que "el nuevo lugar de la problemática de la verdad es el lenguaje [...]. El lenguaje es el lugar donde la realidad se nos hace accesible, donde nos podemos entender unos a otros, donde actuamos, donde reflexionamos. Los límites del lenguaje son los límites de nuestro mundo (Wittgenstein); el lenguaje es universal y al mismo tiempo histórico y finito (Heidegger, Gadamer) [...]. A pesar de su finitud e historicidad el lenguaje no es arbitrario ni puramente subjetivo, sino forma de realización de la comunicación y argumentación intersubjetivas. Pero como sea que esté estructurado el lenguaje, en él no solo se muestra un fenómeno lingüístico, sino que también lo real [...] Así, el lenguaje es al mismo tiempo lugar de la verdad, medium de la argumentación e instrumento de la reflexión" (82).

Cuando presentábamos la estructura fundamental de la verdad de la fe, lo hicimos atendiendo a los dos polos desde los cuales se constituye dicha experiencia de la verdad: desde Dios, la presentamos como acontecimiento de la revelación (2.1); y, desde el hombre, como acontecimiento de la libertad y del amor (2.2). Esta relación dialogal en la que acontece la verdad, además, la comprendimos como un camino que, en la dynamis del Espíritu, se dirige hacia aquella consumación plena y definitiva en la que Dios será "todo en todos" (1 Cor 15, 28). Desde esta estructura fundamental del acontecimiento de la verdad queremos ahora averiguar, invitados a ello por las consideraciones hermenéuticas anteriores (3.1), de qué modo esa misma relación en la que acontece la verdad, acontece en el lenguaje. Para ello, atenderemos a tres cuestiones específicas: primero nos preguntaremos por el carácter dialogal del lenguaje (3.2), luego por su carácter social y cultural (3.3) y, finalmente, queremos abordar de modo general, una pregunta que ha surgido en varias ocasiones en este seminario: si la verdad es acontecimiento del ser en el lenguaje, y a este solo

(81) Mariano de la Maza, "La experiencia de la verdad según Hans-Georg Gadamer”, en: C. Franken (ed.), Verdad e imaginación en la filosofía, teología historia y literatura, Ediciones Universidad Católica de Chile, Santiago 2000, 41-42.

(82) H.-M. Baumgartner, "Wahrheit/Gewissheit", 266.267. 
accedemos mediante el diálogo, en las condiciones concretas de nuestra cultura, entonces: ¿es necesaria la superación de la metafísica?

\subsection{El carácter dialogal de la verdad}

Reconociendo que las características y exigencias del lenguaje son diversas (83), no se puede obviar el hecho de que, quizás, la más original de todas ellas consiste en su carácter dialogal (84). Por ello, podemos partir de la constatación básica de que quien articula y formula el lenguaje lo hace siempre en relación a un alter, a un otro al que se le reconoce igualmente su condición de sujeto libre y responsable. Sin este reconocimiento del otro es una mera ilusión pensar que el lenguaje pudiera ser efectivamente dialogal. Ahora bien, y en segundo lugar, reconocer al otro como verdadero sujeto, implica la preocupación por articular y formular un lenguaje que sea no solo inteligible en virtud de su cualidad lógica, sino que lo sea para el otro (85). Como afirma H.-G. Gadamer, "el que habla un idioma que ningún otro entiende, en realidad no habla. Hablar es hablar a alguien. La palabra ha de ser palabra pertinente, pero esto no significa solo que yo me represente a mí mismo lo dicho, sino que se lo haga ver al interlocutor" (86). En tercer lugar, precisamente por su carácter dialogal, el lenguaje proferido será también una interpelación para que el oyente o receptor responda desde su propia libertad a él. De este modo, "el lenguaje es un hecho interhumano que necesita de la polaridad del yo y del tú para la vida. Consiste en un recíproco dar y recibir que se realiza en el diálogo [...]. Del mismo modo que el locutor ha puesto en juego su poder y su libertad, tiene también que prestar atención al poder y libertad del que responde. Es un hombre igual que el otro. Así, pues, quien se decide a hablar tiene también que escuchar; para hallar audiencia ha de prestarla a su vez" (87).

Estas tres condiciones de posibilidad para un lenguaje dialógico -reconocimiento del otro como sujeto, inteligibilidad relacional y no solo lógica, y disposición a escuchar- nos pueden ayudar a reflexionar críticamente acerca de cómo muchas veces comprendemos la verdad. En primer lugar cabe preguntarse por el efectivo reconocimiento que hacemos del otro como sujeto libre y responsable: ¿Se ha tomado suficientemente en cuenta que una de las característica de la sociedad

(83) Wolfgang Beinert, por ejemplo, asigna ocho características fundamentales al lenguaje: es algo dado, es siempre lenguaje humano (en el sentido que a través de él se constituye el hombre como tal), es autocomunicación, es diálogo, es social, está referido culturalmente, es el instrumento de objetivación de nuestras experiencias y de su incorporación a los elementos del conocimiento ya existentes y, por último, el lenguaje es comunicación de algo (en: Introducción a la teología, Herder, Barcelona 1981, 81-85).

(84) H.-G. Gadamer afirma que "el lenguaje solo existe en la conversación”, indicando así que este carácter dialógico es intrínseco a él y no una mera posibilidad (en:, Verdad y método, vol. II, Sígueme, Salamanca 1992, 203).

(85) Cf. W. Beinert, Introducción a la teología, Herder, Barcelona 1981, 92.

(86) H.-G. Gadamer, Verdad y método, Sígueme, Salamanca 1992, 150. Si Platón expuso su filosofía en diálogos escritos -afirma el mismo Gadamer- fue porque "consideró un principio de verdad que la palabra solo encuentra confirmación en la recepción y aprobación por el otro y que las conclusiones que no vayan acompañadas del pensamiento del otro pierden vigor argumentativo" (p. 205).

(87) W. Beinert, Introducción a la teología, Herder, Barcelona 1981, 83. 
moderna es que en ella el hombre se reconoce a sí mismo como un sujeto autónomo, capaz de construir su destino histórico y de decidir responsablemente respecto a las circunstancias de su vida? Por adecuado que sea hablar de una autonomía solo relativa, en virtud de los múltiples condicionamientos del ser humano y, especialmente, por su referencia absoluta a Dios, ¿justifica ello establecer una comunicación con los demás en la que muchas veces el otro, simplemente, se siente considerado como un menor de edad, como un sujeto incapaz de pensar, de optar y de actuar responsablemente?

En segundo lugar, respecto a la inteligibilidad relacional y no solo lógica del lenguaje nos parece conveniente atender aún mucho más al hecho de que las acciones lingüísticas son de índole plural, y que debido a ello, por ejemplo, una "misma expresión lingüística puede producir efectos totalmente distintos según la respectiva situación coloquial" (88). Es necesario reconocer que "lo dicho nunca posee su verdad en sí mismo, sino que remite, hacia atrás y hacia adelante, a lo no dicho. Toda declaración está motivada; es decir, cuando se dice algo, es razonable preguntar '¿por qué lo dices?' y solo si se entiende eso no dicho juntamente con lo dicho es inteligible un enunciado" (89). Reconocer al otro como verdadero sujeto no es hacerlo en abstracto, sino atendiendo a la situación exacta en la que el otro se encuentra respecto al diálogo y, a la vez, implica poder explicitar también con transparencia el porqué de lo que se dice. Así será posible formular un lenguaje efectivamente inteligible, capaz de interpelar, de suscitar en el otro una respuesta desde su propia libertad. Como ha dicho el Cardenal Paul Poupard, "para que el Evangelio pueda penetrar eficaz y delicadamente en las culturas, hasta sus raíces, deber ser entendido por ellas, debe hablarse en su lenguaje" (90). Me parece que muchas veces nuestra preocupación se ha centrado más en una inteligibilidad lógica que en una dialogal. Para establecer un diálogo efectivo con la sociedad no basta la formulación de un lenguaje que solo exprese la adaequatio intellectus et rei, él también debe ser capaz de probar su adaequatio ad personam. Aunque la inteligibilidad de un lenguaje no sea estrictamente un criterio para juzgar acerca de su verdad, ella sí constituye, al menos, la posibilidad de hacerlo. Por otra parte, también para hacer posible el diálogo, es necesario adquirir la mayor lucidez posible respecto al "desde dónde" estamos hablando, desde qué preocupaciones, desde qué preguntas y problemas reales. Y no pensemos, por favor, solo en la palabra del Magisterio eclesiástico, sino que también en la de la propia teología, cuya inteligibilidad relacional deja aún mucho más que desear. Se podría decir que la palabra del Magisterio se escucha, aunque sea con múltiples distorsiones. ¿Pero aquella de la teología? Considero que los teólogos, como lo ha propuesto Clemens Sedmak, debemos efectivamente atender a que aquella advertencia que Jesús dirigió a los letrados de su tiempo: "Os digo que de toda palabra ociosa que hablen los hombres darán cuenta en el día del Juicio" (Mt 12, 36) (91).

(88) J.Schmitz, Filosofía de la religión, Herder, Barcelona 1987, 155

(89) H.-G. Gadamer, Verdad y método, vol. II, Sígueme, Salamanca 1992, 151.

(90) P. Poupard, "El dinamismo cultural de la fe", Scripta Theologica 25 (1993) 1062.

(91) Cf. C. Sedmak, Theologie in nachtheologischer Zeit, Grünewald, Mainz 2003, 9. 
Y en tercer lugar, respecto a la disposición a escuchar pienso que también habría mucho que pensar y aprender. Si lo que en verdad queremos es establecer un diálogo con los demás, porque pensamos que es en ese diálogo donde puede acontecer la verdad, entonces no queda otra posibilidad que reconocer al otro como un auténtico interlocutor, como a alguien que también tiene algo que decir (92). Esto significa que el otro no está allí simplemente para escuchar, comprender y obedecer. El otro no es un sujeto anónimo, pasivo, meramente receptivo. Como afirma Gadamer, "la verdadera realidad de la comunicación humana consiste en que el diálogo no impone la opinión de uno contra la de otro, ni agrega la opinión de uno a la del otro a modo de suma. El diálogo transforma una y otra" (93). Desde un interés y una actitud dialogal los cristianos debiéramos reconocer al otro como un sujeto capaz de responder a la interpelación que viene del Espíritu de la verdad. De la capacidad que tengamos para escuchar esta respuesta y, sobre todo, para aprender de ella, para dejarnos transformar por ella, dependerá ya no solo nuestra actitud de diálogo, sino nuestra práctica efectiva en favor de él y de la verdad (94).

\subsection{El carácter sociocultural de la verdad}

Decíamos también que el lenguaje posee un carácter sociocultural. Esto significa, por una parte, que toda comunicación se establece al interior de una comunidad lingüística, donde aquellos que participan de la comunicación no inventan el lenguaje sino que, al menos en parte, "ya lo encuentran dado" (95). Y, por otra, significa también que "el lenguaje refleja siempre aquella determinada visión del mundo, que viene dada por el contexto cultural y que influye en todos los usuarios" (96).

Estos dos hechos nos deben hacer reflexionar sobre el contexto en el que se despliega el lenguaje y la comunicación. El primero de ellos nos indica que, al menos muchas veces, no se da una correspondencia exacta entre aquello que se quiere comunicar y aquello que el otro, de hecho, percibe y comprende. Y es que el lenguaje, al menos en parte, tiene una significación que supera la voluntad de aque-

(92) Hans-Georg Gadamer afirma, a nuestro juicio con razón, que "el no oír y el oír mal se producen por un motivo que reside en uno mismo. Solo no oye, o en su caso oye mal, aquel que permanentemente se escucha a sí mismo, aquel cuyo oído está, por así decir, tan lleno del aliento que constantemente se infunde a sí mismo al seguir sus impulsos e intereses, que no es capaz de oír al otro [...] El hacerse capaz de entrar en diálogo a pesar de todo es, a mi juicio, la verdadera humanidad del hombre" (en: Verdad y método, vol. II, Sígueme, Salamanca 1992, 209).

(93) H.-G. Gadamer, Verdad y método, vol. II, Sígueme, Salamanca 1992, 184-185.

(94) Un ejemplo paradigmático de lo que aquí decimos lo constituye, a nuestro juicio, el número 44 de la Gaudium et spes, donde se habla de la "ayuda que la Iglesia recibe del mundo". Aquí "la Iglesia reconoce los muchos beneficios que ha recibido de la evolución histórica del género humano. La experiencia del pasado, el progreso científico, los tesoros escondidos en las diversas culturas, permiten conocer más a fondo la naturaleza humana, abren nuevos caminos para la verdad y aprovechan también a la Iglesia [...] la Iglesia necesita de modo muy peculiar la ayuda de quienes, por vivir en el mundo, sean o no sean creyentes, conocen a fondo las diversas instituciones y disciplinas y comprenden con claridad la razón íntima de todas ellas". Et passim.

(95) W. Beinert, Introducción a la teología, Herder, Barcelona 1981, 83-84. "La verdad es que estamos tan íntimamente insertos en el lenguaje como en el mundo" (H.-G. Gadamer, Verdad y método, vol. II, Sígueme, Salamanca 1992, 148).

(96) W. Beinert, Introducción a la teología, Herder, Barcelona 1981, 84. 
llos que participan en la comunicación. En nuestro caso, nos será muy difícil expresar a la sociedad una actitud dialogal y de servicio, utilizando expresiones y realizando acciones que no dan cabida a la crítica, al disenso, o al menos, a la búsqueda. Cuando alguien se declara a sí mismo como poseedor de la verdad absoluta, para así darle consistencia a su argumentación, con ello ya ha dicho mucho más de lo que él mismo, quizá, quería decir. Ante ello no cabe más que el acatamiento o el rechazo global; no solo de aquello que se quiso decir, sino lo que es más grave, del interlocutor mismo.

Tomar conciencia del segundo hecho que indicábamos, vale decir, de la visión de mundo implícita en el lenguaje, puede ayudarnos a revisar críticamente el desde donde nos estamos comunicando. Independientemente de nuestra voluntad, nuestro lenguaje está, de hecho, condicionado culturalmente. Nuestros símbolos, nuestros ritos, nuestra teología, nuestras instituciones, etc., no expresan inmediatamente un "algo esencial", ni menos un "Alguien". Todo nuestro lenguaje expresa también aquella cultura o culturas que le dieron origen y lo hicieron posible. La cuestión no está, evidentemente, en procurar sustraerse a dichos condicionamientos culturales. Se trataría de una empresa imposible, además de innecesaria. Más bien, de lo que se trata, es de poder efectivamente establecer una diferencia entre aquello que se quiere comunicar y el lenguaje a través del cual ello se hace. Al establecer esta diferencia se podrá discernir mejor aquello que pertenece al núcleo del mensaje evangélico de lo que son sus formas históricas de expresarlo.

En esta edad hermenéutica de la razón -al menos mientras esta sea la comprensión epocal del pensar- pareciera que la verdad teológica debe atender mucho más fundamentalmente a los condicionamientos culturales en los que acontece el lenguaje, a fin de articularse efectivamente como un discurso pertinente. No se trata este de un desafío nuevo; la historia de la teología es la historia de las sucesivos intentos por articular una comprensión de la revelación de Dios de acuerdo a las condiciones, posibilidades y desafíos de cada tiempo. Entre los tantos ejemplos que de ello se pueden dar, para nuestro actual universo de preguntas, me parece particularmente interesante aquella obra de Pierre Charron (1541-1603), que se reconoce como la primera expresión de la apologética moderna, y que publica el año 1593 bajo el título "Les trois vérités contre les athes, idolatres, juifs, mahumetans, heretiques et schismatiques" (97). Los tres tratados de la apologética que desde entonces se hicieron clásicos, y a los que aún hoy se les reconoce un valor heurístico por la distinción que se establece entre los diversos niveles del discurso (las preguntas por el conocimiento de Dios, por la auténtica fe revelada y la verdadera Iglesia) (98) no se formulan desde una lógica interna del pensamiento teológico -o del teólogo-, sino que de cara a quienes se reconocieron como los principales interlocutores de la fe católica. Así, la demostratio religiosa se formula contra los ateos e idólatras; la demostratio christiana, contra los judíos y mahometanos; la demostratio catholica, contra los herejes y cismáticos. La verdad teológica entra aquí en diálogo -aunque

(97) La obra principal de Charron (1541-1603) es Le traité de la sagesse, publicada en Bordeaux el año 1601. Cf. F.Maliske, "Charron, Pierre", LThK 2 (1986) 1032.

(98) Cf. H.Verweyen, Gottes letztes Wort. Grundriss der Fundamentaltheologie, Friedrich Pustet, Regensburg ${ }^{4} 2002,46$. 
sea en forma apologética- con grupos diferenciados de personas, con ella no se dice simplemente, sino que se dice para alguien. Y cuando se dice para alguien no se trata de cambiar el envoltorio, sino de entrar en auténtico diálogo con nuestro interlocutor; el otro, con sus preguntas, objeciones y modos particulares de ser y de pensar, necesariamente modifica aquella verdad que queremos comunicar. Y la modifica no solo en su forma sino que también en su fondo, en la comprensión que hasta ahora hemos tenido de ella. Pero, a la vez, esta verdad modifica, cambia, transforma al receptor. De lo contrario se trataría de un simple proceso de acomodación de la verdad de la fe.

\section{4 ¿Superar la metafísica?}

La verdad se nos manifiesta como acontecimiento del ser en el lenguaje y a él solo accedemos mediante el diálogo, en las condiciones concretas de nuestra cultura. ¿Implican estas afirmaciones la necesidad de superación de la metafísica? A esta cuestión queremos responder, de modo general, en este último punto.

Herbert Schnädelbach distingue cuatro tipos de crítica a la metafísica en el pensamiento contemporáneo (99): aquella que se formula desde la perspectiva de la crítica del conocimiento (escepticismo, Descartes, Kant), de la crítica del sentidosignificado (Wittgenstein), de la crítica ideológica (Marx, Nietzsche), y desde la crítica ontológica (Heidegger, Derrida). La capacidad crítica de cada una de estas perspectivas, sin embargo, se funda en que ellas mismas postulan una "orientación general" (Gesamtorientierung) y, en cuanto lo hacen, son también metafísica (100). La diferencia estaría en que estas perspectivas buscan validarse en referencia a la finitud y no a un sentido "incondicionado". En la misma dirección, Welte considera que tipos de pensamiento positivistas como los de Karl R. Popper o Rudolf Carnap, aunque sean ellos mismos críticos respecto de la metafísica, representan, más bien, una expresión acabada de ella: afirmaciones que no sean falseables o verificables, según el modelo de las ciencias empíricas, caen bajo la sospecha de no tener sentido real (101).

También W. Pannenberg ha reconocido en la propuesta de "superación de la metafísica", diversos acentos, perspectivas y supuestos (102). Tampoco para Pannenberg hoy es posible una metafísica que pretenda validarse como una "fundamentación última del ser y del conocimiento, construida esta desde conceptos. El pensamiento metafísico, más bien, deberá asumir la forma de una reconstrucción conjetural, que se diferencia de la verdad a la que aspira, pero que, al mismo tiempo, se reconoce como forma provisoria de dicha verdad. Su forma de pensar característica será más la antici-

(99) Cf. H.Schnädelbach, "Metaphysik und Religion heute", en: M. Lutz-Bachmann (ed.), Metaphysikkritik, Ethik, Religion, Echter, Würzburg 1995, 15 y s.

(100) Según H. Schnädelbach, "Una destrucción crítica de la metafísica, que efectivamente alcance el núcleo de esta, solo es posible como su reconstrucción" ("Metaphysik und Religion heute", art. cit. 16).

(101) Cf. B.Welte, "Die Krisis der dogmatischen Christussaussagen", en: Zeit und Geheimnis, 301 y s.; véase también: B. Welte, "Jesus Christus und die Theologie", en: J. Sauer (ed.), Wer ist Jesus Christus?, Herder, Freiburg-Basel-Wien 1977, 159 y ss.

(102) W. Pannenberg, Metaphysik und Gottesgedanke, Vandenhoeck und Ruprecht, Göttingen 1988, 7-19. 
pación que el concepto, en el sentido de la metafísica clásica. Dicho más exactamente: El mismo concepto filosófico se mostrará como anticipación" (103).

Bernhard Welte, en una entrevista que concedió el año 1976, consideraba que una de las tareas más importantes del pensamiento teológico y filosófico contemporáneos, es la de poder llegar a pensar un "Dios postmetafísico". Y entiende por tal, "un Dios que no sea construible a partir de un sistema conceptual, sino que se fundamente desde experiencias originarias" (104). Lo que Welte critica al pensamiento metafísico es, justamente, su pretensión de disponer de Dios bajo la forma del concepto y de la acción. Su problema no es "la metafísica", cuanto la pretensión del hombre que en ella se ha amparado (105).

En esta perspectiva, se llamará metafísica, justamente, a este pensamiento epocal que, olvidando el ser del ente, se ha vuelto exclusivamente hacia su entidad, buscando comprenderlo mediante el recurso a conceptos que lo puedan representar, determinar y asegurar. De este modo, escribe Welte, el pensamiento "comienza a hacerse más poderoso que el Dios de la metafísica. Y, en este hacerse más poderoso, el pensamiento comienza a determinar y a disponer de los entes y, así, también del ente supremo, del Dios de la metafísica. Una vez iniciado este proceso, resulta consecuente que, por este mismo camino, el pensamiento también levante su mano contra Dios y lo mate. Así, según Heidegger, la proclamación que hace Nietzsche de la muerte de Dios, es solo una consecuencia extrema de la realización del destino occidental del ser, a través del cual el pensamiento representativo de la subjetividad humana instauró su dominio" (106). La superación de la metafísica consistirá, consecuentemente, en acoger las nuevas posibilidades epocales que se le abren al pensamiento, en pensar lo no pensado y olvidado de todo el pensamiento occidental, en volver al destino original del ser. Este será, según Heidegger, el comienzo de una superación del dominio de la metafísica: la vuelta a las raíces y a los orígenes, la atención del pensamiento al ser y a sus manifestaciones (107).

(103) W. Pannenberg, Metaphysik und Gottesgedanke, op. cit., 68

(104) B. Welte, "Atheismus oder verborgene Religiosität? Ein Gespräch mit Prof. Bernhard Welte", Herderkorrespondenz 30 (1976) 194.

(105) Ya en un escrito publicado el año 1967 (Rückblick auf die Metaphysik”, en: Wort un Wahrheit 22 (967) 747-757), Welte se había ocupado de responder al cuestionamiento de Heidegger del pensamiento metafísico y a la propuesta de este en orden a la superación de la metafísica. Más interesante aún es una carta que Welte escribe a M. Heidegger el 4 de marzo de 1960. En ella, después de agradecerle el envío de una edición especial de Hegel und die Griechen, le dice lo siguiente: "Cada vez me queda más claro, que Hegel también se sitúa en un punto decisivo de la historia de la teología. Creo ver cada vez más claramente cómo la historia de la teología participa a su modo de la historia de la metafísica occidental, cómo el cristianismo, pensado desde antiguo en las categorías griegas, se siguió pensando por ese camino, a través de Anselmo y sus seguidores medievales, y cómo llegó en Hegel a su plenitud, pero con él, también a su fin. Todo me habla en favor de que con la interpretación hegeliana del cristianismo ya no puede haber una teología como la anterior, y que en el futuro la teología no podrá acontecer sin pasar por Hegel y con ello sin la superación de Hegel y de todo cuanto en él se sintetiza".

(106) B. Welte, "Gott im Denken Heideggers", en: Zeit und Geheimnis, 269.

(107) En su Carta sobre el humanismo, por ejemplo, M. Heidegger escribe: "Damit wir erst lernen, das genannte Wesen des Denken rein zu erfahren und das heisst zugleich zu vollziehen, müssen wir uns frei machen von der technischen Interpretation des Denkens. Deren Anfänge reichen bis zu Plato und Aristoteles zurück. Das Denken selbst gilt dort als eine technéh, das Verfahren des Überlegens im Dienste des Tuns und Machens" (M. Heidegger, Brief über den "Humanismus", en: M. Heidegger, Wegmarken, Vittorio Klostermann, Frankfurt a.M. ${ }^{2} 1978,312$ ). 
Ahora bien, autores como Schnädelbach, consideran que para evitar esta pretensión del hombre de disponer de Dios bajo la forma del concepto y de la acción, no es necesario despedirse de la metafísica. Más bien, se requiere terminar con el discurso de su superación, y desarrollar una "metafísica crítica". "La metafísica crítica se resiste contra la falsa positivización de las 'cosas últimas' (letzter Dinge) -sea de la historia, del progreso, de la voluntad de poder o del sentido incondicionado- y, así, abre el horizonte a nuevas experiencias y a la libertad humana; esta filosofía primera no es la prima philosophia, que ataca Adorno. La metafísica, como orientación cognitiva general con medios interpretativos desde la perspectiva de la finitud no debe temer a la metafísica crítica; sus formas son ellas mismas formas críticas de la metafísica y, como tales, realizaciones crítico-metafísicas" (108).

En un sentido semejante, Verweyen plantea la necesidad de una philosophia prima (109), pero que no identifica con "la metafísica". Considero importante su planteamiento por las siguientes razones. Primero: en su planteamiento da cuenta la historia del concepto de philosophia prima, explicando cómo este ha tenido distintos usos tanto en la filosofía como en la teología. En efecto, en Aristóteles la philosophia prima designa la ciencia que trata del "ente en cuanto ente", que se pregunta por el fundamento último de todo aquello que puede ser objeto de conocimiento. En esta pregunta, sin embargo, no se tematiza la mediación que establece el sujeto respecto de su objeto. Esto lo hará recién Descartes y luego Kant, para quienes la reflexión sobre el sujeto y sus estructuras apriorística son condición para el conocimiento del mundo y de todo posible "más allá -o detrás- de las cosas físicas" ( $\tau \alpha$

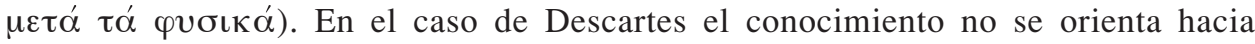
ningún saber más allá de las cosas, sino al mundo objetivo, como "res extensa". Las "pruebas de la existencia de Dios" le servirán para asegurar una evidencia matemática y, así, construir un método seguro de acceso a la "res extensa". La pureza del conocimiento matemático ("more geometrico") se constituirá también en el ideal del conocimiento para Leibniz y determinará la comprensión del conocimiento en las ciencias positivas, desde el siglo XIX en adelante. Las bases de la lógica matemática formuladas por Leibniz serán desarrolladas por Frege, Carnap y Russel, para constituirse en soportes de la técnica y de lo que hoy denominamos "realidad virtual". Pero junto a esta línea de desarrollo de la philosophia prima, que de hecho derivó en una fundamentación de las ciencias positivas, desde el siglo XVII la Schulphilosophie insistirá más sobre el carácter general, fundamental y principal que el concepto debía connotar, y, así en autores como Wolff (1679-1754), la filosofía -además de ser ejercida "more geometrico"-, ella debía ser "ontología”. En el siglo XIX, aunque el concepto de philosophia prima caiga en desuso, él será reivindicado por la escolástica, y luego, durante el siglo XX, para postular una ontología distinta a la metafísica (110).

Este breve recorrido histórico del concepto de philosophia prima nos indica, en primer lugar, que el postulado de una philosophia prima -ni antes ni ahora- ha

(108) H. Schnädelbach, "Metaphysik und Religion heute", art. cit., 29.

(109) H.Verweyen, Gottes letztes Wort. Grundriss der Fundamentaltheologie, Friedrich Pustet, Regensburg ${ }^{4} 2002,58$ y ss.

(110) Cf. J. Ferrater Mora, Diccionario de Filosofía, vol. 3, Alianza, Madrid 51986, 2568-2569. 
estado necesariamente vinculado a la metafísica. El mismo concepto de "metafísica" fue dado por Andrónico de Rodas, en el siglo I antes de Cristo, a los libros de Aristóteles que, ordenados por letras del alfabeto griego, estaban "detrás de las cosas físicas", pero que él mismo había denominado "filosofía primera" (prote pilosopía). Pero, de hecho, se ha establecido una equivalencia entre los conceptos de filosofía primera y metafísica. Y, cuando esto ha sucedido, ha sido causa de diversos problemas. Ya por estas mismas razones históricas parece aconsejable no reivindicar ni rechazar "la" metafísica, sin previamente esclarecer el significado que se le asigna a este concepto y especificar bajo qué respectos se entiende, o no, en relación a la filosofía prima (111).

Teniendo presente estas vicisitudes históricas del concepto de philosophia prima y la necesidad de que ella no se asocie a cualquiera de las formas en que se ha desarrollado "la metafísica", el planteamiento de Verweyen también lo considero de interés, en segundo lugar, porque él reivindica la filosofía primera no en contra de la hermenéutica, sino al servicio de ella, como el lugar donde las convicciones que esta alcanza se deben verificar. La filosofía primera no concurre con aquella apertura radical de la comprensión hermenéutica, sino que la funda, preguntándose por sus condiciones de posibilidad. Pero, al mismo tiempo, la filosofía primera no debe considerarse al margen del mismo proceso hermenéutico. Aunque ella no sea "ancilla hermeneuticae", afirma Verweyen, ella queda referida a la paradoja fundamental de la "autonomía regalada", paradoja que tiene lugar justamente en ese proceso hermenéutico que la filosofía primera no puede construir, sino que encuentra como algo dado.

En este mismo sentido, Welte comprende la religión como una realidad previamente dada al pensamiento, y, por tanto, como algo que este no puede -desde sí y ante sí- construir o destruir arbitrariamente. Ahora bien, para la filosofía se trata de una realidad previamente dada "solo como el ámbito objetivo al que esa mirada se refiere en el acto de pensar. Pero su derecho y su esencia ante la razón han de acreditarse todavía. Por eso, lo dado previamente no es la base de la que debamos partir como de una evidencia" (112). Tampoco la filosofía primera podría reducirse a este "antes" de la pregunta por las condiciones y posibilidades del proceso hermenéutico que tiene lugar en la religión, puesto que, de hacerlo, perdería toda su potencialidad crítica (113). En efecto, cuando la filosofía primera se pregunta por las condiciones y posibilidades últimas de aquello que encuentra dado, y esto lo hace desde la fuerza de la inteligencia que tiene de sí y del ser, entonces ella ya no solo queda internamente referida a la paradoja de la "autonomía regalada", sino que, además, procurará ser una reconstrucción crítica de aquello previamente dado, con

(111) La sugerencia de José Ferrater Mora, aunque un tanto extrema, da bien cuenta del problema: "en vista de la variedad de opiniones sobre la metafísica, es casi obvio que no hay nada que pueda llamarse "la metafísica". Hay modos de pensar filosóficos muy diversos que conllevan diversos tipos de metafísicas, a menudo incompatibles entre sí. Parece razonable entonces o abstenerse de discutir acerca de si es legítima o no "la" metafísica, o eliminar en lo posible esta palabra del vocabulario filosófico. Lo que se haga entonces filosóficamente será lo que importa, no si se llama o no "metafísica" (Cf. J. Ferrater Mora, Diccionario de Filosofía, vol. 3, Alianza, Madrid 51986, 2202).

(112) B. Welte, Filosofía de la religión, 29 (el subrayado es mío).

(113) Cf. B. Welte, Filosofía de la religión, 34. 
miras a su auténtico ser y esencia (114). De este modo, la filosofía primera no se quedará en la facticidad de lo dado, sino que se preguntará por su esencia, por aquello que se manifiesta al pensamiento como ser y verdad. La respuesta a esta pregunta por el ser y la verdad será expresada en conceptos que, de hecho, podrán ser mejor formulados. Sin embargo, advierte Verweyen, esta necesidad fáctica de corregir los conceptos a los que llega la filosofía primera no debe confundirse con la necesidad ineludible de preguntarse siempre de nuevo por las condiciones y posibilidades últimas de los sentidos hermenéuticos transmitidos (115).

Como explica Grondin, "contra la voluntad metafísica y explícitamente hegeliana del comprender, Gadamer apeló explícitamente al modelo dialógico platónico, cosa que también se podía malentender fácilmente, porque, precisamente desde las lecturas de Heidegger y Nietzsche, se considera a Platón como padre de la metafísica. La verdad que se puede experimentar y alcanzar en el diálogo no tiene nada que ver con una toma de posesión. Mucho más legítimo parece hablar de una participación en la verdad, porque en el diálogo con otros y consigo mismo, en tanto que pensamos, llegamos a encontrar verdades que nos parecen probables sin saber cómo y qué nos pasa. Y no somos dueños de estas verdades, sino más bien son ellas las que en cierto modo toman posesión de nosotros. El que entiende puede experimentarse como alguien que sufre estas verdades cuando vive un encuentro con el sentido, con la evidencia y la orientación. En relación con ello, Gadamer recuerda la frase de Heráclito: 'El relámpago lo guía todo', una frase que estaba grabada sobre la puerta en la cabaña de Heidegger. El relámpago significa aquí 'lo repentino de la iluminación que hace visible de golpe, como un relámpago, todas las cosas, pero de tal manera que la oscuridad vuelve a devorarlas inmediatamente'. Visto así, la verdad del entender tiene mucho más el significado de una participación que el de una apropiación total y definitiva y, en cualquier caso, está muy lejos de un dominio metafísico del saber" (116).

B. Welte destacará en el pensamiento de M. Heidegger el hecho de que él haya reconocido que el mismo pensar filosófico no es meramente constructivo, sino que apertura al ser que se manifiesta en todo cuanto es. Para Heidegger, afirma Welte, el "pensar es agradecer" (117). Y efectivamente, al cumplir sus 85 años, el 26 de septiembre de 1974, M. Heidegger regala un poema a Winfried Herrmann en el que escribe: "Que más instaurador que el instaurar, y más fundador que el pensar, quede el agradecimiento. A quienes han alcanzado el agradecer, los vuelve aquel a poner ante la presencia de lo inaccesible, a la cual nosotros -los mortales todos- desde el inicio somos apropiados" (118).

La concepción de una participación en la verdad y de la dependencia constante del diálogo testifican la imposibilidad de dar con un sentido objetivado tal como podría sugerirlo la metafísica de la presencia y la filosofía clásica del lenguaje.

(114) Cf. B. Welte, Filosofía de la religión, 29.

(115) Cf. H. Verweyen, Gottes letztes Wort. Grundriss der Fundamentaltheologie, Friedrich Pustet, Regensburg ${ }^{4} 2002,71-72$.

(116) J. Grondin, Introducción a la hermenéutica filosófica, Herder, Barcelona 1999, 193-194.

(117) B. Welte, "Das Denken. Martin Heidegger 85 Jahre", Christ in der Gegenwart 26 (1974) 302.

(118) Citado por Otto Pöggeler, El camino del pensar de Martin Heidegger, Alianza Universidad, Madrid 21993, 536-537. 
También aquí hay que recurrir a la intuición de la palabra interior del alma, porque la filosofía hermenéutica sostiene que nunca se puede alcanzar del todo una palabra de la aspiración interior del alma. Ninguna palabra o signo puede tomarse como la presencia definitiva de un sentido. Es simplemente señal, différance, si se quiere, o el diferir hacia algo otro que solo se puede indecir. El lenguaje vive de esta imposibilidad de satisfacer esta aspiración, de la capacidad de soportar la différance entre la palabra y lo que se quiere decir (119).

Para el Papa Juan Pablo II, la metafísica es la filosofía que tiende "a la contemplación de la verdad y a la búsqueda del fin último y del sentido de la vida" y la distingue de otras racionalidades que, "como "razón instrumental", están orientadas, o pueden estarlo, al servicio de fines utilitaristas, de placer o de poder" (120). Por todo lo dicho anteriormente, la razón de la crítica a "la metafísica" no radica en que esta se haya ocupado de la contemplación de la verdad y de la búsqueda del fin último y del sentido de la vida", como propone el Papa, sino que, por el contrario, en ella ha operado una "razón instrumental", que ha buscado someterlo todo al concepto, para así someterlo y dominarlo todo. En este sentido, la voluntad de poder no solo ha operado en la razón instrumental, sino que también en la metafísica.

¿Y entonces qué? Entonces el desafío es, efectivamente, dirigir el pensamiento hacia la contemplación de la verdad, hacia la búsqueda del fin último, hacia el sentido de la vida. Pero ello no basta, se requiere lucidez para reconocer aquella voluntad de poder que opera en todo conocimiento, y de libertad para reconocer la primacía de la verdad, sobre toda representación que nos podamos hacer de ella. En esta perspectiva, se debe reconocer -además- la insuficiencia de una razón que aspira a cuantificarlo todo, medirlo todo, pronosticarlo todo, definirlo todo, distinguirlo todo, sistematizarlo todo, etc. Está claro que estas acciones del intelecto son necesarias, pero también es claro que no es principalmente a través de ellas como el espíritu humano puede llegar a la contemplación de la verdad, a reconocer el fin último y el sentido de la vida. Estaría a la mano decir, entonces, que aquello de lo que se requiere es de "la contemplación". Siendo ello correcto, también pensamos que es insuficiente.

¿Y entonces? Entonces el desafío es dirigir el pensamiento hacia la búsqueda y la contemplación de la verdad. Y aquí me parece plenamente pertinente, entre otras tantas acciones de la inteligencia que pudieran contribuir a este mismo propósito, reconocer el potencial programático que pudiera tener para la razón aquella práctica tan característica en Pablo y que, en general, en el Nuevo Testamento se expresa a

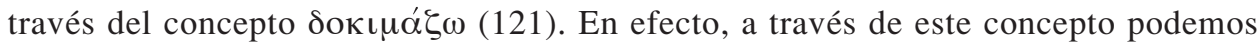
reconocer que el pensamiento no se dirige hacia el encuentro y la contemplación de la verdad de modo inmediato, sino que interpretando, discerniendo, probando. Aho-

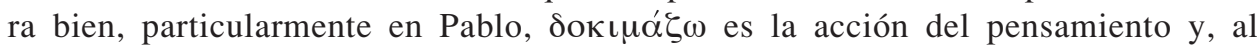
mismo tiempo, es una acción vital, a través de la cual algo, y principalmente alguien, es reconocido, probado, interpretado en la verdad de aquello que es (122). A

(119) J. Grondin, Introducción a la hermenéutica filosófica, Herder, Barcelona 1999, 195.

(120) Juan Pablo II, Fides et ratio, 47.

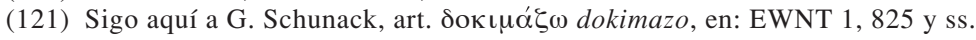

(122) Cf. G.Schunack, art.cit., 826. 
este acto, por tanto, "corresponde el ser, que en una relación adecuada, se puede reconocer y comprender; este acto se expresa en un discernimiento crítico, como también en la verificación práctica de lo conocido, tanto de cara a sí mismo como a los demás. Lo propio en Pablo será comprender este acto del "intepretar" como una comprensión crítica y práctica, como una responsabilidad ante la misma fe, ante el Señor, ante el conocimiento de Dios en Cristo; y, por ello, se trata de un acto que el creyente y la comunidad deben realizar de modo reflexivo y comunicativo" (123)

Conocido es el texto del Evangelio donde Jesús denuncia la hipocresía de quienes saben intepretar los aspectos del cielo, pero no saben interpretar este tiem-

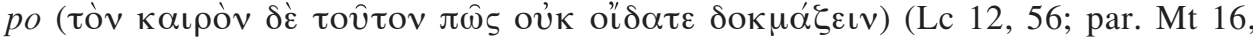
$3)$. Aquí también se trata, como se refuerza en el versículo siguiente del relato de

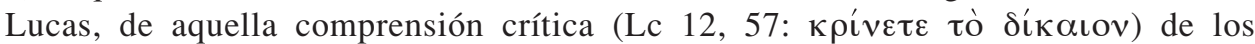

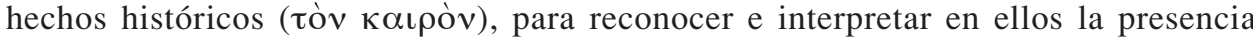
salvífica de Dios. Se trata, efectivamente, de una capacidad del entendimiento para discernir críticamente la voluntad de Dios, su presencia actuante en el mundo, su acción salvífica en Cristo (cf. Rom 1, 18 y ss.). De este modo, el pensamiento que se dirige a la búsqueda y contemplación de la verdad, no queda remitido a una idea sobre Dios, a una idea sobre su justicia o sobre su bondad, sino que al acontecimiento escatológico de la salvación de Dios en Cristo, que podemos ya reconocer, interpretar, experimentar en "este tiempo". La criticidad aquí no es una tarea optativa de la inteligencia, sino inherente a ella, puesto que es conciente de la hipocresía y de la injusticia en que puede quedar atrapada la verdad.

\section{LA VERDAD Y LA TRADICIÓN}

Pareciera que otra de las cuestiones que en esta "edad hermenéutica de la razón" se ha hecho problemática es la comprensión teológica del concepto de tradición. La conciencia de que la verdad es un acontecimiento del ser en el lenguaje y, por tanto, que a ella solo podemos acceder mediante el diálogo, dificultan la comprensión de una verdad que -ante toda vicisitud histórica- debe ser guardada y transmitida, por fidelidad al encargo que hemos recibido del mismo Cristo y Señor. En este último capítulo queremos, precisamente, abordar esta cuestión, mostrando cómo para la misma filosofía hermenéutica la tradición constituye un eje central de su comprensión de la verdad (4.1) y reflexionando sobre el lugar de la tradición en el acontecimiento de la verdad de la fe (4.2).

\subsection{Verdad y tradición en la filosofía hermenéutica}

No hay auténtica identidad personal o social sin tradición; las tradiciones son parte constitutiva de nuestra identidad actual y futura; no somos sin pasado, sin cultura, sin historia. Y, por cierto, tampoco hay hermenéutica sin tradición. La hermenéutica se constituye principalmente de cara al pasado, para comprender el presente y orientar hacia el futuro. La hermenenéutica lo es de tradiciones, escritas u

(123) G. Schunack, art.cit., 826. 
orales, formales o informales, de prácticas o de símbolos, que de diversos modos nos han sido transmitidas y constituyen hoy nuestro presente, dándole a este identidad y sentido. Ya en este plano antropológico-fundamental es posible reconocer una estrecha relación entre hermenéutica y tradición (124), cuestión expresamente abordada por Gadamer cuando en su obra Verdad y método trata de "los prejuicios como condición de la comprensión” (125).

En efecto, para Gadamer, "el punto del que parte el problema hermenéutico", "la pregunta central de una hermeneútica que quiera ser verdaderamente histórica", lo constituye la teoría crítica de los prejuicios elaborada por la Ilustración. De acuerdo a la idea cartesiana del método, el presupuesto fundamental de la Ilustración será que "un uso metódico y disciplinado de la razón es suficiente para proteger de cualquier error". De este modo, así como "la precipitación es la fuente de equivocación que induce a error en el uso de la propia razón, la autoridad, en cambio, es culpable de que no se llegue siquiera a emplear la propia razón" (126). Para historiadores como Johann Georg Walch (1693-1775), la reforma impulsada por Lutero habría debilitado profundamente tanto el respeto hacia "el Papa filosófico" (= Aristóteles) como hacia el Papa romano y, así, habría preparado a un correcto uso de la razón (127). La oposición que la Ilustración establece entre fe en la autoridad y uso de la propia razón solo tiene fundamento, considera Gadamer, "en la medida en que la validez de la autoridad usurpa el lugar del propio juicio, la autoridad es de hecho una fuente de prejuicios. Pero esto no excluye que pueda ser también una fuente de verdad, cosa que la Ilustración ignoró sistemáticamente en su repulsa generalizada contra toda autoridad" (128).

A través del concepto de tradición, acuñado por el romanticismo, Gadamer intenta superar el antagonismo que la Ilustración había planteado entre autoridad y razón, y que hasta ahora pareciera dominar la comprensión misma de la verdad. El mérito del romanticismo fue reconocer el poder fáctico de la tradición: al margen de los fundamentos de la razón, la tradición conserva siempre algún derecho y determina ampliamente nuestras instituciones y comportamiento (129). El romanticismo, sin

(124) Como afirma H.-J. Pottmeyer, “... la tradición es a la vez destino y reto. La apropiación personal, es decir, libre e inteligente, de la tradición motiva una actitud crítica respecto de la tradición. La apropiación personal de la tradición requiere su interpretación. El transmisor y el receptor deben relacionar la tradición con su respectiva situación y experiencia e interpretar recíprocamente la experiencia recordada y presente, si no se quiere que el recuerdo vivo se transforme en tradicionalismo muerto. La tradición viva es interpretación y exige interpretación; comprende continuidad e innovación. Por eso el proceso de la tradición no carece nunca de conflictos... Los transmisores y receptores transmiten y reciben lo transmitido interpretándolo. Por otra parte, lo transmitido determina, marca y transforma tanto a los transmisores como a los receptores, y además el proceso de la tradición, sus formas e instituciones" (H.-J. Pottmeyer, “Tradición”, en: R. Latourelle, R. Fisichella y S. Pié-Ninot, Diccionario de Teología Fundamental, San Pablo 1992, 1562).

(125) En Verdad y método, Sígueme, Salamanca 1991, 344 y ss.

(126) H.-G. Gadamer, Verdad y método, Sígueme, Salamanca 1991, 345.

(127) J.-G. Walch, Philosophisches Lexicon, 1726, 1013 (citado por H.-G. Gadamer, Verdad y método, Sígueme, Salamanca 1991, 345)

(128) H.-G. Gadamer, Verdad y método, Sígueme, Salamanca 1991, 346.

(129) "Lo consagrado por la tradición y por el pasado -afirma Gadamer- posee una autoridad que se ha hecho anónima, y nuestro ser histórico y finito está determinado por el hecho de que la autoridad de lo transmitido, y no solo lo que se acepta razonadamente, tiene poder sobre nuestra acción y sobre nuestro comportamiento [...]. Las costumbres se adoptan libremente, pero ni se crean por libre determinación ni su validez se fundamenta en esta" (H.-G. Gadamer, Verdad y método, Sígueme, Salamanca 1991, 348). 
embargo, comprenderá la tradición como lo contrario de la libertad racional, verá en ella un dato histórico como pudiera serlo la naturaleza y, así, aparece también como contrapartida abstracta de la libre autodeterminación. En este sentido, dirá Gadamer, "la fe romántica en las "tradiciones que nos han llegado", ante las que debería callar toda razón, es en el fondo igual de prejuiciosa e ilustrada. En realidad la tradición siempre es también un momento de la libertad y de la historia. Aun la tradición más auténtica y venerable no se realiza, naturalmente, en virtud de la capacidad de permanencia de lo que algún modo ya está dado, sino que necesita ser afirmada, asumida y cultivada" (130). De este modo, la tradición acontece siempre como acto de la libertad, en el que incluso la decidida voluntad de conservación representa -al menos en principio- una conducta tan libre como la voluntad de transformación y de innovación de las tradiciones recibidas.

Por las razones anteriores, tanto la antítesis del romanticismo como la antítesis de la ilustración, consideran la tradición como un objeto a disposición del sujeto, como si este pudiera afirmarla o rechazarla de acuerdo a su propio querer y parecer. Con ello, dirá Gadamer, no se atiende al hecho antecedente de cualquier decisión respecto de la tradición, cual es el que "nos encontramos siempre en tradiciones, y este nuestro estar dentro de ellas no es un comportamiento objetivador que pensara como extraño o ajeno lo que dice la tradición; esta es siempre más bien algo propio, ejemplar o aborrecible, es un reconocerse en el que nuestro juicio histórico posterior no se aprecia apenas conocimiento, sino un imperceptible ir transformándose al paso de la misma tradición" (131). Una de las experiencias en las que este "ser en tradiciones" se manifiesta es aquello que denominamos "clásico", por cuanto ello "no asigna una cualidad que se atribuya a determinados fenómenos históricos, sino un modo característico del mismo ser histórico, la realización de una conservación que, en una confirmación constantemente renovada, hace posible la existencia de algo que es verdad [...]. En el fondo lo clásico no es realmente un concepto descriptivo en poder de una conciencia histórica objetivadora; es una realidad histórica a la que sigue perteneciendo y estando sometida la conciencia histórica misma [...]; es una conciencia de lo permanente [...]; una especie de presente intemporal que significa simultaneidad con cualquier presente" (132). Se pude afirmar que "lo clásico" constituye una mediación histórica del pasado con el presente, y, así, expresa adecuadamente la tarea hermenéutica fundamental, que es, precisamente, comprender en el acontecer de la tradición, donde el pasado y el presente se hallan en continua mediación (133). Por ello, "el verdadero topos de la hermenéutica", lo constituye aquel punto medio entre extrañeza y familiaridad en la que nos encontramos en el acontecer de la tradición, "el punto medio entre la objetividad de la distancia histórica y la pertenencia a una tradición" (134)

Coherentemente con la anterior, la "comprensión hermenéutica" planteada por Gadamer no opera por la vía de la exclusión de la tradición, sino que por el contrario ella acontece al interior mismo de esa tradición. Lo que pretende el

(130) H.-G.Gadamer, Verdad y método, Sígueme, Salamanca 1991, 349.

(131) H.-G.Gadamer, Verdad y método, Sígueme, Salamanca 1991, 350.

(132) H.-G.Gadamer, Verdad y método, Sígueme, Salamanca 1991, 356.357.

(133) Cf. -H.G.Gadamer, Verdad y método, Sígueme, Salamanca 1991, 360.

(134) H.-G.Gadamer, Verdad y método, Sígueme, Salamanca 1991, 365. 
famoso "círculo hermenéutico" es -justamente- no resolver la pregunta por la verdad por la vía de la exclusión, sino por la vía de la inclusión, del acercamiento sucesivo a cuanto se manifiesta como ser. Como explica Gadamer, "el movimiento de la comprensión va constantemente del todo a la parte y de esta al todo. La tarea es ampliar la unidad del sentido comprendido en círculos concéntricos. El criterio para la corrección de la comprensión es siempre la congruencia de cada detalle con el todo. Cuando no hay tal congruencia, esto significa que la comprensión ha fracasado" (135).

Siguiendo el planteamiento de Heidegger, respecto de la importancia del "movimiento anticipatorio de la comprensión", Gadamer afirma que el círculo hermenéutico -particularmente en relación a la comprensión de textos-, tiene un carácter propiamente ontológico: no es "de naturaleza formal; no es subjetivo ni objetivo, sino que describe la comprensión como la interpretación del movimiento de la tradición y del movimiento del intérprete. La anticipación de sentido que guía nuestra comprensión de un texto no es un acto de la subjetividad sino que se determina desde la comunidad que nos une con la tradición. Pero en nuestra relación con la tradición, esta comunidad está sometida a un proceso de continua formación. No es simplemente un presupuesto bajo el que nos encontramos siempre, sino que nosotros mismo la instauramos en cuanto que comprendemos, participamos del acontecer de la tradición y continuamos determinándolo así desde nosotros mismos. El círculo de la comprensión no es en este sentido un círculo 'metodológico' sino que describe un momento estructural ontológico de la comprensión" (136).

La cuestión crítica de la hermenéutica, según la entiende Gadamer, no está por tanto en la exclusión de la tradición en un función de un supuesto ejercicio libre y autónomo de la razón, sino en "distinguir los prejuicios verdaderos bajo los cuales comprendemos, de los prejuicios falsos que producen malos entendidos. En este sentido, una conciencia formada hermenéuticamente tendrá que ser hasta cierto punto también conciencia histórica, y hacer conscientes los propios prejuicios que le guían en la comprensión, con el fin de que la tradición se destaque a su vez como opinión distinta y acceda así a su derecho" (137). Como conciencia histórica, la conciencia hermenéutica deberá considerar en su proceso de comprensión las múltiples modificaciones en las que se ha desarrollado la tradición en que ella habita. A la atención de los efectos que los hechos de la tradición han tenido en la historia, Gadamer le llama "historia efectual" (Wirkungsgeschichte). Su valor, de nuevo, no está en la objetivación de la tradición, al modo del objetivismo histórico, sino en las posibilidades que la historia efectual abre a la comprensión, como un momento interno a ella, operante y determinante (138). La conciencia de la "historia efectual"

(135) H.-G.Gadamer, Verdad y método, Sígueme, Salamanca 1991, 361.

(136) H.-G.Gadamer, Verdad y método, Sígueme, Salamanca 1991, 363.

(137) H.-G.Gadamer, Verdad y método, Sígueme, Salamanca 1991, 369.

(138) En el campo de la exégesis bíblica, consideramos que el comentario que hace Ulrich Luz al Evangelio según Mateos, constituye un ejemplo destacado del potencial que tiene la Auslegunggeschichte en la comprensión de los testimonios bíblicos. Lo mismo puede decirse, entre otros ejemplos, del comentario a Carta de Pablo a los Gálatas, de Franz Mussner. En ambos casos la historia de la interpretación no se reduce a una compilación de información histórico-positiva, sino que se integra al proceso mismo de la comprensión. 
es conciencia de la situación hermenéutica, es decir "de la situación en la que nos encontramos frente a la tradición que queremos comprender” (139),

\subsection{Verdad y tradición de la fe}

Reconociendo la validez del planteamiento de Gadamer respecto de la tradición, es necesario advertir que el punto de partida hermenéutico del concepto de tradición de la fe le da a esta un carácter que la tradición filosófica no posee. Para el cristianismo la tradición surge y se constituye desde una Verdad acontecida en la historia, tiene por misión ser memoria histórica de dicho acontecimiento, ser actualización escatológica de la salvación plena y definitiva que ha acontecido en Cristo. Al insertarse en este acontecimiento escatológico de Cristo, la tradición cristiana es un acontecimiento de alcance universal por cuanto, por la acción del Espíritu Santo, en la Iglesia y en el mundo, ella busca interpelar a cada hombre y mujer en las condiciones concretas de su historia y de su mundo. Este origen divino, su carácter misionero y su pretensión de universalidad, le otorgan a la tradición de la fe un sentido que la tradición filosófica no posee, al menos, no necesariamente. Con esta "delimitación" previa no pretendemos situar la tradición de la fe fuera de sus condiciones y posibilidades humanas, como si se tratara de una cuestión de un orden del todo distinto -por ejemplo, "sobrenatural"-; más bien, queremos advertir sobre la posibilidad de establecer aquí, de nuevo, un concordismo tan fácil como inútil. Hecha la advertencia, sobre el suelo de las anteriores consideraciones filosóficohermenéuticas queremos ahora preguntarnos por la textura propia de la tradición de la fe, en el entendido que solo a través de ella podemos participar del acontecimiento de la verdad.

Jesús y la Iglesia apostólica ante la tradición

Ante la pregunta de cómo Jesús se habría comportado respecto de la tradición, una respuesta "de acuerdo a nuestros tiempos" sería afirmar que lo hizo "con total libertad". En efecto, "Jesús no hace caso del día festivo (Mc 3, 1-7a par.; Lc 13, 1017 ; 14, 1-6; Jn 5, 1.9b.10; 9, 14); no respeta las prescripciones sobre lavados rituales (Lc 11, 38) y aprovecha la extrañeza que causa su conducta para atacar la hipocresía (ibid. 39-41); denuncia la observancia minuciosa que encubre la violación de lo esencial (Mt 23, 23s; Lc 11, 42); declara inválida las prescripciones del AT sobre la distinción de puro e impuro (Mc 7, 18s par; Rom 14, 14), que Él mismo había violado tocando a un leproso (Mt 8, 3 par.); rechaza la concepción farisea del sábado (Mc 2, 23-26 par.), declara que el hombre es superior al precepto (Mc 2, 27s), ataca el legalismo (Mc 3, 4 par.), no reconoce validez a la Ley mosaica sobre el divorcio (Mc 10, 4-12 par.)" (140). Pero la pregunta es la siguiente: ¿esta práctica se explica por una cuestión de "libertad" respecto de la Ley, o, más bien, por una cuestión de fidelidad al espíritu latente en ella? Miremos un poco más de cerca este asunto.

(139) H.-G. Gadamer, Verdad y método, Sígueme, Salamanca 1991, 372

(140) Sigo aquí a Juan Mateos, "Vocabulario bíblico-teológico", en: J.Mateos - L.A.Schökel, Nuevo Testamento, Cristiandad, Madrid, ${ }^{2} 1987,1298$. 
"No penséis que he venido a abolir la Ley y los Profetas. No he venido a abolir, sino a dar cumplimiento [ $\pi \lambda \eta \rho \hat{\omega} \sigma \alpha \iota]$ " (Mt 5, 17). En este texto -que según U. Luz es "uno de los más difíciles del Evangelio" (141) - se expresa una de las cuestiones centrales con las que se debió confrontar Jesús y la Iglesia primitiva: ¿el anuncio del reinado de Dios supone ahora una abolición de la Ley mosaica, de la Antigua Alianza, del Judaísmo? El análisis exegético del versículo mateano recién citado -que, según Tertuliano, Marción quiso eliminar, y que, en todo caso los marcionitas simplemente cambiaron, por la oposición que establecían entre el Dios del Antiguo y del Nuevo Testamento (142) - nos indica la radical importancia que tuvo para Jesús mostrar cómo sus hechos y palabras eran el cumplimiento de las promesas de Dios (143), cuestión de la que dan cuenta también otros importantes testimonios neotestamentarios. Por ejemplo, en el compendio del Evangelio de Marcos leemos: "El tiempo se ha cumplido [ $\pi \varepsilon \pi \lambda \eta \dot{\eta} \rho \omega \tau \alpha \iota]$ y el reino de Dios está cerca; convertíos y creed en la Buena Nueva" (Mc 1, 15). Y en Lucas, en un texto que hace las veces de "compendio", se afirma que Jesús, después de leer la promesa que Dios había hecho a su Pueblo a través del Profeta Isaías (Is 61, 1-2), “comenzó a decirles: 'Esta Escritura que acabáis de oír se ha cumplido [ $\pi \varepsilon \pi \lambda \eta \dot{\rho} \rho \omega \tau \alpha \iota]$ hoy"” (Lc 4, 21).

Escribe San Pablo en la carta a los Romanos: “... pensamos que el hombre es justificado por la fe, independientemente de las obras de la ley. ¿Acaso Dios lo es únicamente de los judíos y no también de los gentiles? ¡Sí, por cierto!, también de los gentiles; porque no más que un solo Dios, que justificará a los circuncisos en virtud de la fe y a los incircuncisos por medio de la fe. Entonces ¿por la fe privamos a la ley de su valor? ¡De ningún modo! Más bien, la consolidamos” (Rom 3, 28-31). El esfuerzo hermenéutico que Pablo hace aquí, como en el resto de la Carta a los Romanos y también en la Carta a los Gálatas, es evidente. Debe demostrar que el acontecimiento de la salvación que, ahora, en Cristo, ha operado por medio de la gracia, no representa una negación de Ley, sino que efectivamente su cumplimiento. La práctica renovada de convocar y reunir a Israel supone que la comunidad de los discípulos se comprende a sí misma como el verdadero Israel. Esto se puede apreciar en dos autodenominaciones que provienen de la comunidad primitiva de Jerusa-

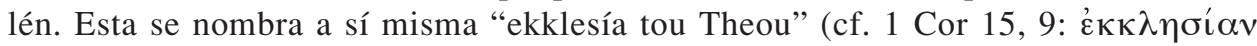

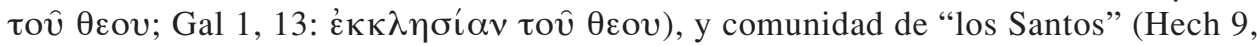

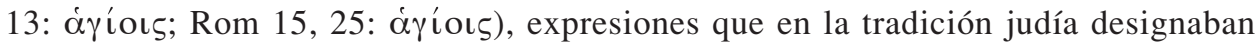
al verdadero pueblo de Dios y al Pueblo de Dios del final de los tiempos, respectiva-

(141) U. Luz, Das Evangelium nach Matthäus (Mt 1-7). Evangelisch-Katholischer Kommentar zum Neuen Testament, Benzinger/Neukirchener Verlag, Zürich-Einsiedeln-Köln, 1985, 230.

(142) Tertuliano, Marc 5, 14, 14 = PL 2, 508 ("frustra de ista sententia neganda Pontus laboravit"). Citado por U.Luz, Das Evangelium nach Matthäus (Mt 1-7). Evangelisch-Katholischer Kommentar zum Neuen Testament, Benzinger/Neukirchener Verlag, Zürich-Einsiedeln-Köln, 1985, 233.

(143) Como afirma H.Waldenfels, "un modelo de la iluminación recíproca de pasado y presente es la relación bíblica entre promesa y cumplimiento. Las palabras del profeta son palabras de su tiempo; mas para las personas que asumieron estas palabras en el horizonte de la lealtad de Dios, con su promesa de salvación o su amenaza de perdición, influyeron en el futuro, provocando la conversión o la perseverancia de los oyentes. Lo que fue promesa en su tiempo, las generaciones posteriores lo percibieron como cumplimiento o como ocasión para conocer las promesas en su propia época de cara al futuro. En esta perspectiva hay que entender las numerosas referencias de Mateo: 'Todo esto sucedió para que se cumpliera"” (H.Waldenfels, Teología fundamental contextual, Sígueme, Salamanca 1994, 90). 
mente (144). Justamente por ello, Pablo interpretará las tradiciones recibidas en el sentido de que se es hijo de Abraham no por la circuncisión sino por la fe (cf. Rom 4 y Gal 3). Para los que creen en Cristo "Abraham es su Padre (Rom 4, 12); ellos son los herederos (Gal 3, 29); los hijos de la promesa (Gal 4, 28); los elegidos (Rom 8, 33); los llamados (Rom 1, 6ss.); los amados de Dios (Rom 1, 7); los hijos de Dios (Rom 8, 16; Gal 3, 26)" (145).

Pero la aplicación de los títulos honoríficos del antiguo Pueblo de Dios a la Iglesia naciente es, en Pablo, aún más radical: los que creen en Cristo han sido hechos "para ser ministros de una nueva Alianza, no de la letra, sino del Espíritu" (2 Cor 3, 6); "sus rostros reflejan, como en un espejo, la gloria del Señor, el esplendor de aquella presencia poderosa con que acompañó a su pueblo por el desierto y que luego residió en el Templo (2 Cor 3, 18); son por el Espíritu Santuario de Dios (1 Cor 3, 9); incluso son los verdaderos circuncisos (Flp 3, 3) puesto que la verdadera circuncisión es la que sucede en el corazón por la acción del Espíritu (Rom 2, 29)" (146).

En estas distintas tradiciones neotestamentarias la clave hermenéutica de cualquier comprensión de la relación entre nueva y antigua Alianza la constituye Cristo mismo. Es Él quien a través de sus hechos y palabras da cumplimiento a las promesas de Dios, lleva a plenitud toda la Ley y los Profetas, realiza la salvación prometida desde antiguo a nuestros padres. Para ello Él "ha venido" (Mt 5, 17). Por la autoridad de quien lo ha enviado las enseñanzas de Jesús serán cumplimiento de la Ley en sentidos diversos pero complementarios: le devolverá a ella su verdadero significado, añadirá lo que a ella le faltaba, o bien, la perfeccionará. Al mismo tiempo, por medio de su práctica dará cumplimiento a la Ley y los Profetas, por cuanto en Él se realizarán las promesas histórico-salvíficas de Dios a su Pueblo, por cuanto en su obediencia al Padre manifestará el sentido más hondo de la Ley, por cuanto a través de su muerte y resurrección -de su vida entregada para la salvación de todos- llevará la Ley tanto a su cumplimiento como a su fin (147). Estos diversos sentidos del cumplimiento de la Ley y de los Profetas se han acentuado de modo diverso a lo largo de la historia de la Iglesia, pero ha prevalecido la comprensión de que se trata de distintas dimensiones del mismo acontecimiento de Cristo, a quien han sido sometidas todas las cosas (cf 1 Cor 15, 28), en quien se ha manifestado la gloria de Dios, la plenitud de la gracia y la verdad (cf Jn 1, 14) (148).

Para Jesús y, consecuentemente, para la comunidad apostólica, dar cumplimiento a las promesas de Dios implica necesariamente interpretar esas promesas

(144) El término ekklesía "en griego normalmente significa asamblea pública, asamblea de la comunidad política. Sin embargo los setenta traducen en varios lugares importantes la palabra qahal, la Asamblea del pueblo de la alianza ante Yahvé, por ekklesía... Particularmente importante es el texto del Deuteronomio 23, 2-9... Aquí ekklesía es comprendida como el verdadero pueblo de Dios" (G. Lohfink, La Iglesia..., 85). Por su parte, la autodenominación de comunidad de "los Santos", la "encontró ya como un terminus technicus y lo aplicó a sí misma. Y desde Daniel 7 este concepto designa al Pueblo de Dios del final de los tiempos" (loc. cit.)

(145) G. Lohfink, La Iglesia..., 88

(146) Ibid., 89.

(147) Cf. U. Luz, Das Evangelium nach Matthäus (Mt 1-7). Evangelisch-Katholischer Kommentar zum Neuen Testament, Benzinger/Neukirchener Verlag, Zürich-Einsiedeln-Köln, 1985, 232.

(148) Cf. U. Luz, Das Evangelium nach Matthäus (Mt 1-7). Evangelisch-Katholischer Kommentar zum Neuen Testament, Benzinger/Neukirchener Verlag, Zürich-Einsiedeln-Köln, 1985, 233-235. 
para devolverle a ellas toda su fuerza liberadora y movilizadora. La "clave hermenéutica" en este proceso de interpretación, sin embargo, no está fuera de la historia salvífica de Dios con su Pueblo; no la constituye una referencia externa al proceso mismo, a través del cual Dios se fue manifestando "muchas veces y de muchas maneras a nuestros Padres por medio de los Profetas" (Heb 1, 1); ni tampoco ella está dada por una teoría, o por una práctica, que se haya agregado al proceso revelatorio de Dios, o deducido de él. Más bien, la clave hermenéutica debe reconocerse en el mismo proceso de autocomunicación de Dios, en la irrupción del reinado escatológico de Dios en nuestra historia, en definitiva, en la persona de Jesucristo. Por ello, Jesús se insertará en las mismas tradiciones proféticas para denunciar la hipocresía que se ha instalado en la religión judía: "Este pueblo me honra con los labios, pero su corazón está lejos de mí. En vano me rinden culto, ya que enseñan doctrinas que son preceptos de hombres" (Mc 7, 6 citando a Is 29, 13). Para Jesús, si así se puede decir, el problema hermenéutico fundamental lo constituye el hecho de que la religión -su culto, doctrina, moral- ya no es expresión histórica de la autenticidad de la fe, sino que en las manos de los hombres, se ha constituido en instrumento de dominio sobre Dios y los hombres. Así, entre otros tantos testimonios que se pudieran aducir, Marcos escribe a continuación del texto recién citado: "Dejando el precepto de Dios, os aferráis a la tradición de los hombres" [...] "Qué bien violáis el mandamiento de Dios, para conservar vuestra tradición” (Mc 7, 8.9).

Como explica Pottmeyer, "la interpretación, como la realizan Pablo y los otros hagiógrafos, es no solo expresión de la necesidad general de la interpretación, si la tradición ha de ser algo vivo. La constante reinterpretación es en la Biblia expresión de la verdad de que el Señor vive y está inmediatamente presente en cada época y en ella es de nuevo testimoniado. Así pues, la Biblia transmite no solo los contenidos de la tradición, sino también modelos de su interpretación" (149). La comunidad de los creyentes se entendió en relación a la tradición de Israel, pero interpretada esta desde el acontecimiento de Cristo. Sin embargo, al asumirse esta nueva clave hermenéutica en el proceso de la tradición se produce un desplazamiento de la tradición hacia la persona de Jesús, hacia el testimonio auténtico de sus hechos y palabras. De este modo, el testimonio de los apóstoles sobre Cristo se convierte en nuevo fundamento de la tradición cristiana.

\section{La tradición como fusión de horizontes}

En el sentido de la hermenéutica, el significado y alcance universal de la traditio supone que el encuentro con el Cristo anunciado solo es posible mediante una "fusión de horizontes", en el que efectivamente puedan reconocerse la Palabra de Dios y la palabra de los hombres (150). De allí el desafío para la traditio de

(149) H.J.Pottmeyer, “Tradición”, en: R. Latourelle, R. Fisichella y S. Pié-Ninot, Diccionario de Teología Fundamental, San Pablo 1992, 1563.

(150) Cf. H.Verweyen, Gottes letztes Wort. Grundriss der Fundamentaltheologie, Friedrich Pustet, Regensburg ${ }^{4}$ 2002, 62. Como explica Mariano de la Maza, el concepto horizonte ya se encuentra en la filosofía de Nietzsche, Husserl y Heidegger para designar "el ámbito de todo lo que es visible desde un determinado punto de vista o situación. La situación en la que nos encontramos nos impide verlo todo de una vez, nos limita. Quien entra en un proceso de comprensión histórica 
poder interpelar a cada hombre y mujer en sus propios horizontes de comprensión, no tan solo epocales o culturales, sino que también en sus propias situaciones vitales. Si ello no llegara a suceder la tradición se interrumpiría, no acontecería verdaderamente, por más que se guardaran y transmitieran íntegramente los distintos testimonios históricos de ella.

Pero como "fusión de horizontes", la tradición de la fe no acontece como simple adaptación de la Palabra de Dios a los horizontes siempre nuevos de comprensión de cada hombre y mujer, de cada cultura. Ciertamente se está ante la tarea de una "reconstrucción" de la verdad que nos ha sido transmitida, de un modo que sea plausible y relevante para el hombre moderno. Sin embargo, esta tarea se debe asumir con la mayor lucidez puesto que a ella la acechan diversos peligros. En primer lugar, en esta adaptación se pudiera ir haciendo una concesión tras otra, de tal modo que, luego, llevaría en sí misma el germen de su propia disolución: la "verdad" transmitida no se distinguiría de las precomprensiones dominantes en la cultura, de las ideologías vigentes, de las representaciones simbólicas dominantes en la sociedad. Se trata de adaptaciones superficiales e ingenuas que, incluso, podrían llevar a una pérdida de la identidad de la verdad revelada en Cristo, de su potencial crítico y transformador de lo dado, de lo socialmente aceptado, de lo moderno (151). En segundo lugar, como dice Peter L. Berger estos intentos sucesivos de adaptación pudieran "terminar pronto por marear" (152): cuando recién se ha terminado de "reconstruir la verdad" según una visión de mundo A -que es la que se reconoce como "moderna"-, se constata que dicha visión de mundo ya ha pasado de moda y que, ahora, es necesario reconstruir todo de nuevo según una visión de mundo $\mathrm{B}$; y así sucesivamente, puesto que "las mercancías se mueven muy rápido en el supermercado cultural moderno" (153). En tercer lugar, y más fundamentalmente, esta tarea de "reconstrucción" debe ser asumida con lucidez, por cuanto conlleva una peligrosa pretensión, cual es, justamente, la de querer "reconstruir la verdad". En esta tal pretensión, la verdad de nuevo sería "una cosa", un objeto a nuestra disposición, algo que nosotros -con las mejores intenciones, quizás- podemos desconstruir o reconstruir ad libitum. Si la tarea efectivamente está animada por esta pretensión, entonces ella poco o nada tiene que ver con la Verdad acontecida en Cristo, ni tampoco con su tradición (154).

procura ampliar su horizonte, enriquecerlo, abrirse a otros horizontes, desplazarse a horizontes pasados. Desplazarse a un horizonte histórico no significa para Gadamer apartar la mirada de sí mismo, con los propios prejuicios y opiniones, hacia otra situación, en la que estos prejuicios y puntos de vista se ven cuestionados. La hermenéutica no debe ocultar la tensión entre los distintos horizontes, sino asumirla conscientemente y desarrollarla de un modo fructífero" (Mariano de la Maza, "La experiencia de la verdad según Hans-Georg Gadamer", en: C. Franken (ed.), Verdad e imaginación en la filosofía, teología historia y literatura, Ediciones Universidad Católica de Chile, Santiago 2000, 39-40).

(151) Cf. Cf. H.Verweyen, Gottes letztes Wort. Grundriss der Fundamentaltheologie, Friedrich Pustet, Regensburg ${ }^{4} 2002,62$.

(152) Peter L. Berger, "Wenn die Welt wankt. Pluralismus ist eine Chance für Christen”, Lutherische Monatshefte 12 (1993) 13

(153) Loc. cit.

(154) Como afirma H.Verweyen, “...die Glaubenssubstanz wird um der Anpassungsfâhigkeit willen geschmeidiger gemacht. Der weltoffene Christ beginnt, medientechnisch versiert, sich in einer Ôffentlichkeit, in der nicht mehr Wahrheit, sondern nur noch "Palusibilität" gefragt ist" (H.Verweyen, Gottes letztes Wort. Grundriss der Fundamentaltheologie, Friedrich Pustet, Regensburg $\left.{ }^{4} 2002,68\right)$. 
¿Cómo podría entonces realizarse históricamente esta "fusión de horizontes” en la tradición de la verdad? Es aquí donde la Verdad se nos muestra también como Camino, según claramente se deja intelegir de la comprensión de la revelación propuesta por el Vaticano II (155). En efecto, el Concilio afirma que en el Verbo encarnado, "quiso Dios, con su bondad y sabiduría, revelarse a Sí mismo y manifestar el misterio de su voluntad (cf Ef 1, 9)"; en Cristo, el "Dios invisible (cf Col 1, 15; 1 Tim 1, 17), movido de amor, habla a los hombres como amigos (cf Ec 33, 11; Jn 15, 14-15), trata con ellos (cf Bar 3, 38) para invitarlos y recibirlos en su compañía". Este "hablar de Dios", por su parte, se realiza "por obras y palabras intrínsecamente ligadas". A diferencia del Vaticano I, que remite la revelación a un acto jurídico por parte de Dios, a un "decreto de su voluntad" (DH 3004), para el Vaticano II la revelación queda referida al "misterio de su voluntad". Como ha sugerido J. Ratzinger (156), el concepto de "misterio" debe entenderse aquí en el mismo sentido que él tiene en la carta a la Efesios citada, es decir, "abarca la universalidad de la salvación ("que todo tenga a Cristo por Cabeza", Ef 1, 10), la unidad de la humanidad en Cristo, la dimensión cósmica de lo cristiano, el carácter histórico de la revelación y, finalmente, su centro cristológico" (157). Por el mismo carácter personal y universal que en Cristo adquiere el misterio de Dios, "la verdad teológica" no es "un en sî", ni tampoco un decreto "para nosotros"; más bien, esta verdad se hace carne, habita entre nosotros, nos habla como a amigos, nos invita y recibe, se manifiesta a través de hechos y palabras, etc. ¿No es en este misterio de la encarnación donde se nos manifiesta el camino para una auténtica "fusión de horizontes"? ¿No es Cristo donde los "horizontes" de Dios y el hombre se han hecho uno, "sin confusión, sin cambio, sin división, sin separación”? ¿No es en Cristo donde la tradición reconoce la estructura dialogal de la verdad?

Para que el diálogo entre Dios y los hombres se pueda verificar en el acontecimiento de la tradición, no solo se requiere de la acción de Dios, sino que también de la acción del hombre. En este sentido, consideramos que la comprensión hermenéutica debe remitir, desde sí misma, a una intelección siempre mayor de aquella Verdad recibida mediante el testimonio de la comunidad creyente. La certeza de la verdad de la fe, como afirma Verweyen, "no se alcanza aun cuando ella se sostiene y confiesa en la simple obediencia de la fe" (158). Para ser parte viva de la tradición de la verdad, el sujeto no solo requiere entender dicha verdad en las propias categorías epocales de su existencia personal y social, sino que además, él deberá ser capaz de pensar por sí mismo el testimonio de la verdad que ha recibido (159). Ciertamente, la fe puede vivir "desde sus propias raíces"; ella "no es una filosofía, sino, más bien, lo otro de la filosofía” (160); la experiencia creyente, efectivamente, "está

(155) Concilio Vaticano II, Dei Verbum, n.2.

(156) Sigo aquí su comentario al Proemio y a los capítulos I y II de la Dei Verbum, en: LThK 13 (1986) 506 y ss.

(157) J. Ratzinger, op. cit., 507.

(158) H.Verweyen, Gottes letztes Wort. Grundriss der Fundamentaltheologie, Friedrich Pustet, Regensburg ${ }^{4} 2002,63$.

(159) A esta cuestión nos hemos referido extensamente en: La verdadera religión, pp. 81 y ss.

(160) B. Welte, Filosofía de la religión, 24. Según Erich Brock, aquella religión que vive desde sus orígenes, y que él llama "piedad natural", no requiere tener tanto temor ante la filosofía. ¿Por qué? Porque "gran parte de la filosofía académica, y de la no académica, es tan aburrida como inofensiva" (E. Brock, Religionsphilosophie, (editada por Ernst Oldemeyer), Francke, Bern 1990, 11). 
previamente dada al pensamiento" (161). Sin embargo, cuando se le requiera, ella debe ser capaz de dar razón de su esperanza (cf. 1 Pe 3, 15); y lo podrá hacer cuando el testimonio de la verdad no solo se funda en la autoridad de otros, sino cuando, por sí mismo, mediante el ejercicio autónomo y libre de su pensamiento, sea capaz de comunicarla convencidamente a otros. De este modo, la traditio deja de ser algo exterior al sujeto, por cuanto ahora puede participar de ella desde el movimiento autónomo de su pensamiento, afirmando ante sí y los demás el carácter definitivo de la verdad recibida por el testimonio de otros.

\section{CONCLUSIONES}

A partir de lo expuesto queremos presentar las siguientes reflexiones conclusivas:

1. El pensamiento teológico se encuentra en un contexto epocal en el que la pregunta por la verdad ha encontrado, de hecho, diversas respuestas: ellas van desde la negación nihilista hasta la afirmación integrista, pasando por el relativismo, el empirismo, el agnosticismo, el pragmatismo, el escepticismo, etc. ¿Son convincentes estas respuestas? Pareciera que no, porque la pregunta permanece y, aunque sea desconfiadamente, ella no solo se dirige a la verdad del ente y de los enunciados categoriales, sino que se atreve a preguntar por su ser: ¿Y qué es la verdad? Tanto las preguntas como las respuestas deben seguir siendo pensadas. Con sobradas razones el pensamiento teológico puede levantar serias objeciones a las comprensiones de la verdad que se manifiestan tanto en las preguntas como en las respuestas de la cultura actual. Pero antes de apresurarse a la objeción, y mucho antes de llegar a la condenación, conviene preguntarse por la verdad que se manifiesta en todo ello. ¿Por qué el nihilismo? ¿Por qué el pragmatismo? ¿Por qué el escepticismo? Y, así, sucesivamente. Probablemente en estas y otras posiciones no solo encontraremos el error, y menos aún la tontera y la maldad, sino también la verdad, en sus múltiples paradojas, aporías, analogías, negaciones, etc.

En el sentido anterior, no solo habría que preguntarse por los "sistemas filosóficos" que han llevado a preguntarse desconfiadamente por la verdad, sino por las mismas experiencias vitales y existenciales que también han hecho posible esta desconfianza y que la han condicionado. En la perspectiva de una hermenéutica de la facticidad, por ejemplo, habría que preguntarse por la relación que existe entre las múltiples expresiones de la crisis de sentido en la sociedad actual y el escepticismo respecto de la verdad. En una cultura en la que predomina una "mentalidad científico-tecnológica", otro ejemplo, no debiera extrañar el hecho de que vayamos adquiriendo, quizás todos, una comprensión pragmática de la verdad. ¿Y qué decir de los enunciados, de las proposiciones, de las doctrinas, que se proponen como verdaderas? ¿Las sospechas que se levantan contra ellas solo tienen que ver con una eventual incoherencia lógica, con la falta de fundamentos racionales, con la debilidad de sus sistemas? ¿La sos-

(161) B.Welte, Filosofía de la religión, 23. 
pecha respecto de la verdad no tiene también que ver con una sospecha respecto de la veracidad - credibilidad de aquellos que dicen poseerla? El mundo de la vida (Lebenswelt) y sus sistemas (sociales, políticos, económicos) siguen siendo la base sobre la cual se construyen nuestras ideas, representaciones y comprensiones de la realidad. La pretensión de pensar la verdad fuera de la facticidad en que ella acontece es una ilusión.

2. En la filosofía hermenéutica -al menos en H.G. Gadamer, uno de sus representantes más destacados- se pueden reconocer importantes impulsos para pensar la verdad en su facticidad histórica. Lejos de negar la verdad, lo que hace la hermenéutica es preguntarse por las condiciones que posibilitan una adecuada comprensión y acceso a ella. La filosofía hermenéutica afirma que la verdad no está, simplemente, en la adecuación entre el intelecto y la cosa; sino que, más bien, ella acontece en el lenguaje y en la tradición como interpretación. ¿Significa esta afirmación una negación de la verdad, de las capacidades de la razón para buscarla y hallarla? Por todas las razones expuestas en el desarrollo de la exposición, consideramos que no. Sin embargo, no se puede eludir el hecho de que se trata de una comprensión problemática, porque cuanto no aspira a la posesión de la verdad, no identifica de modo unívoco el concepto con la cosa, no parte ni llega a un punto cero o final. En el interpretar "siempre de otra manera" la comprensión de la verdad queda siempre remitida a lo inacabado del concepto, a lo provisorio de la idea, a lo inconcluso del pensar. ¿La conciencia de la imperfección de nuestro conocer y de nuestro saber implica claudicar ante la pregunta por la verdad? A nuestro entender, muy por el contrario. Significa asumir el desafío a seguir pensando, a no detenerse nunca ante lo ya alcanzado, a reconocer siempre de nuevo el acontecer de la verdad en todo cuanto es. Lo dicho respecto de la superación de la metafísica tiene aquí lugar.

3. La comprensión de la verdad en la filosofía hermenéutica nos ha ayudado a mirar nuestras propias tradiciones, para desde ellas comprenderla como acontecimiento escatológico del encuentro entre Dios y el hombre, destacando en ello tres momentos de una relación dialogal: el de la iniciativa de Dios, como revelación; el de la respuesta del hombre, en la libertad y el amor; y el de su realización, como un camino en la dynamis del Espíritu, que se dirige a hacia aquella consumación plena y definitiva en la que Dios será "todo en todos" (1 Cor 15, 28). Lo decisivo para esta comprensión teológica de la verdad ha sido reconocer la propia estructura dialógica de la verdad de la fe. Esta no acontece como un "en sî" en Dios, ni tampoco acontece como producto del ingenio humano. Más bien, ella se manifiesta en el diálogo al que hemos sido invitados por Dios en nuestra propia historia. El Dios que nos habló "muchas veces y de muchas maneras", ha querido hablarnos ahora, "en estos últimos tiempos", por medio de su Hijo, Jesucristo (cf. Hb 1, 1 y ss.). Y, para ello, "la Palabra se hizo carne" (Jn 1, 14). Esta concentración ontológico-personal del hablar de Dios ha puesto "la cuestión de la verdad", a nuestro entender, en un registro enteramente nuevo. Y la novedad no radica, por cierto, en la palabra, en el decir, en las enseñanzas que ahora Dios, quizás más cerca, nos ha querido transmitir a través de su Hijo. Lo nuevo radica en que todo ello "se hizo 
carne"; es decir, la verdad deja de ser la sola propiedad de un enunciado, de un concepto, de una doctrina; la verdad, "en estos últimos tiempos", se nos ha manifestado en Cristo mismo, "lleno de gracia y de verdad" (Jn 1, 14). En Cristo la verdad acontece en una unidad indisoluble de "hechos y palabras" y queda, así, asociada a nuestra propia carne. Y si así Dios nos ha querido hablar, entonces nuestra respuesta a la verdad revelada ya no puede consistir en el solo "asentimiento del intelecto". Por la gracia del Espíritu de la verdad, nuestra respuesta deberá verificarse en nuestros propios "hechos y palabras", en nuestra propia carne, en la libertad y en el amor. En esta transitividad se manifiesta la única fuerza del Espíritu de la verdad, que cuando lo acogemos mediante la fe, nos configura con Cristo y nos permite llamar a Dios Abbá. De este modo, verdad-libertad-amor se integran y corresponde en el único movimiento de la fe, posibilitado por la acción del Espíritu.

4. Hemos afirmado, también, que la verdad de la fe, como acontecimiento escatológico del encuentro entre Dios y el hombre, se realiza siempre de nuevo en el lenguaje. En esta perspectiva, nos ha interesado especialmente mostrar cómo la verdad, para que pueda acontecer en nuestra historia, requiere atender a las estructuras internas del lenguaje, a su carácter propiamente dialogal y al contexto sociocultural en el que se realiza. El diálogo entre Dios y el hombre no es un diálogo desinteresado, abstracto, sobre las condiciones y posibilidades de lo que es, o de lo que no es. El diálogo de Dios con el hombre es un diálogo de salvación, está lleno de interés, está movido por el interés de la vida, de la libertad y del amor (Jn 10, 10). Ciertamente, la verdad de la fe no acontece fuera del lenguaje; pero como lenguaje queda siempre referido hacia quien está más allá de toda teoría y de toda práctica, esto es, de todo lenguaje. No pretendemos aquí insinuar las virtudes de la teología apofática, o de la teología negativa, que por cierto las tienen. Más bien, en nuestra exposición nos ha interesado la pregunta de cómo el lenguaje de la fe, principalmente el de la teología, contribuye eficazmente al encuentro entre Dios y el hombre. Y si como lenguaje de la fe se articula en aquel acontecimiento nostrae salutis causa, entonces la teología ya no se podrá autosatisfacer en la sola inteligencia lógica de sus proposiciones, en sus disquisiciones más o menos ingeniosas, en los sistemas conceptuales que pueda construir. Como lenguaje de la fe en la teología también podrá acontecer la verdad, en ella también se podrá expresar inteligentemente el encuentro de Dios con el hombre, en ella se podrá expresar el interés de Dios por la salvación de todos los hombres.

5. Por último, hemos querido hablar de la tradición porque nos ha parecido que para nuestro contexto epocal, y también eclesial, se trata de una cuestión de suma importancia. Como se explicó, a través del concepto de tradición se ha intentado superar el antagonismo que la Ilustración planteó entre autoridad y razón, y que hasta ahora ha dominado la comprensión misma de la verdad. Sobre el suelo de este mismo antagonismo hoy también se ha levantado la alternativa entre autoridad y subjetividad, reivindicando no tanto la autonomía de la razón, cuanto la autonomía e inmediatez de la experiencia sensorial. En este contexto, se ha propuesto un concepto general de tradición al interior del cual se puedan reconocer los momentos de la libertad y de la historia. Desde 
este concepto general, hemos destacado el origen divino, el carácter misionero y la pretensión de universalidad, como rasgos propios de la tradición de la fe. Esta tradición de la fe, tanto en Jesús como en la comunidad de los que creyeron en Él, está animada por aquella estructura fundamental de promesa-cumplimiento, en la que cada uno de los polos queda siempre referido al otro en una tensión siempre nueva e irreductible. Ahora bien, la cuestión es que el dar cumplimiento a las promesas de Dios, tanto para Jesús como para la comunidad, implicó, necesariamente, interpretar esas promesas y tradiciones, para devolverle a ellas toda su fuerza liberadora y movilizadora. En esta perspectiva, hemos reconocido que la tradición de la verdad de la fe no se alcanza por la sola proclamación de aquello que hemos "visto y oído", ni por la consecuente obediencia de la fe. Para que la tradición de la fe acontezca en la verdad, es necesario que ella sea memoria viva, en la historia, del encuentro de Dios con el hombre. La comunidad de los creyentes, guiada por el Espíritu de la verdad, ha sido constituida por Cristo para ser signo e instrumento eficaz en la historia "del Amor y de la Verdad que se han dado cita, de la Justicia y de la Paz que se besan, de la Verdad que brota de la tierra, de la Justicia que se asoma desde el cielo" (Sal 85, 11).

\section{RESUMEN}

Entre las tantas cuestiones disputadas en relación a la hermenéutica, una de las que ha generado mayor interés y que ha sido motivo de mayor preocupación ha sido la relativa a la cuestión de la verdad: en particular, a nuestras posibilidades de conocerla y de comunicarla a otros. En este contexto general de la cuestión de la verdad en la hermenéutica, el artículo siguiente busca esclarecer las posibilidades de una comprensión teológica de la verdad que, siendo consecuente con las reglas internas del trabajo teológico, a la vez, dé cuenta de los principales aportes de la filosofía hermenéutica, los cuales son reconocidos, principalmente, en dos cuestiones que tienen un carácter fundamental, tanto para la teología como para la filosofía hermenéutica: la comprensión del lenguaje (punto 3.) y su acontecer en la tradición (punto 4.). El autor situará ambas cuestiones en directa relación con la comprensión que la hermenéutica (punto 1.) y la teología (punto 2.) tienen de la verdad.

\section{ABSTRACT}

Among the many debated issues concerning hermeneutics, one which has captured particular attention, and which has been a matter of great concern, is the one regarding truth: specifically, our possibilities of getting to know truth and communicating it to others. Within this context of the place of truth within hermeneutics, this article seeks to shed light on the likelyhood of a theological understanding of the truth, in accordance to the internal rules of theological work, and to account for the main contributions of hermeneutic philosophy, marked by two key, issues fundamental for theology and philosophy: language comprehension (point 3 ) and its occurrence in tradition (point 4). The author deals with both issues, relating them directly to hermeneutics and the theological understanding of truth. 